\title{
Assessment and Removal of Emerging Water Contaminants
}

\author{
Honglan Shi', Xiaoliang Cheng ${ }^{2}$, Qihua $\mathbf{W u}^{1}$, Ruipu $\mathrm{Mu}^{1}$ and $\mathrm{Yinfa}_{\mathrm{Ma}}{ }^{1 *}$ \\ ${ }^{1}$ Department of Chemistry and Environmental Research Center, Missouri University of Science and Technology, Rolla, MO, USA \\ ${ }^{2}$ Life Sciences Division, Lawrence Berkeley National Laboratory, Berkeley, CA, USA
}

\begin{abstract}
This review summarizes recent literature related to analytical method development, assessment, and removal of emerging contaminants in natural water resources and drinking water. This review mainly focuses on the following four groups of chemical contaminants: pharmaceuticals and personal care products (PPCPs); major disinfection byproducts, cyanotoxins, and pesticides and herbicides. Because of the large volume publications on various emerging environmental contaminants, articles relating to specific water treatment, health risk assessments and ecological impact are not included in this review. In addition, literature pertinent to emerging contaminants in air and other environments are also not covered in this review.
\end{abstract}

Keywords: Emergency water contaminants; PPCPs; DBP; Cyanotoxins; LC-MS/MS; Pesticides and herbicides removal

\section{Introduction}

In recent years, because of the advanced analytical instrumentation and new analytical techniques, scientists have been able to detect very low concentrations of many chemicals in natural and drinking waters. These low levels of emerging contaminants in natural waters and drinking waters may not cause immediate lethal effect to humans but may promote disastrous impacts on human health in a long term. While the risk that low concentrations of emerging contaminants pose to humans and the environment requires further investigation, it is important to identify the concentrations of these compounds in natural and treated drinking waters so that effective techniques can be developed to remove these contaminants. Although no direct adverse impact on human health and ecological systems has been established from consuming drinking water that contains very low levels of some emerging contaminants, the potential for their long term accumulative effect on human health has caused a public concern.

To address the emerging contaminant issues, many university research laboratories, federal agencies such as the Environmental Protection Agency (EPA), and public drinking water branches have done a fair amount of research and screening to quantify each category of emerging contaminants, including disinfection by products (DBPs), pharmaceuticals and personal care products (PPCPs), pesticides and herbicides, cyanotoxins, endocrine disrupting chemicals (EDCs), persistent organic pollutants (POPs), micro-constituents, and others. Several key reviews have covered progressive studies on emerging contaminants in source waters and drinking waters in the past years [1-9]. Several organizations, such as EPA, American Water Works Association (AWWA), and Potomac Drinking Water Source Protection Partnership (Potomac DWSPP's), and many others, have taken proactive actions in providing funding to support and promote research on emerging contaminants in natural water resources and drinking waters, and organizing workshops and meetings to deliver messages to the public. In addition, the findings and occurrence data of significant emerging contaminants, often called "contaminants of emerging concern" (CECs), are reported in the annual reports for public review.

To minimize levels of these emerging contaminants, the US EPA has finalized its Contaminant Candidate List 3 (CCL3) in 2009, which is composed of a total of 116 drinking water contaminants. These 116 contaminants have already been detected in public water systems in the US and/or pose the risk of existing in public water supplies. Under the Safe Drinking Water Act (SDWA), the EPA is required to evaluate and determine whether to regulate at least five contaminants from the CCL every five years. Also, the EPA is required to issue a new list of no more than 30 unregulated contaminants to be monitored by public water systems (PWSs) every five years. The data in Unregulated Contaminant Monitoring Rule (UCMR) has been used in regulatory determinations as well. Currently, UCMR3 has been published and UCMR2 compounds may be regulated in the near future. The critical issue is that once those emerging contaminants are regulated, all of the drinking water systems will be required to monitor those contaminants regularly.

In this review, the recent publications related to analytical method development, assessment, and removal of emerging contaminants in natural water resources and drinking water will be summarized to provide relatively comprehensive information to the researchers in this field. However, due to the large variety of lists of emerging contaminants, it is not possible for this review to cover all of them. This review mainly focuses on the following four groups of chemical contaminants: pharmaceuticals and personal care products (PPCPs); major disinfection byproducts, cyanotoxins, and pesticides and herbicides. The publications pertinent to specific water treatment technologies (such as free chlorine, monochloroamine, permanganate, ozone, UV, etc.), health risk assessments and ecological impact are not included in this review. In addition, literatures pertinent to emerging contaminants in air and other environments are also not covered in this review.

*Corresponding author: Yinfa Ma, Department of Chemistry, Missour University of Science and Technology, 400 West, 11th Street, Rolla, MO 65409, USA, Tel: 573-341-6220; Fax: 573-341-6033; E-mail: yinfa@mst.edu

Received July 12, 2012; Accepted November 20, 2012; Published November 23, 2012

Citation: Shi H, Cheng X, Wu Q, Mu R, Ma Y (2012) Assessment and Removal of Emerging Water Contaminants. J Environ Anal Toxicol S2:003. doi:10.4172/2161 0525.S2-003

Copyright: (c) 2012 Shi H, et al. This is an open-access article distributed under the terms of the Creative Commons Attribution License, which permits unrestricted use, distribution, and reproduction in any medium, provided the original author and source are credited. 


\section{Assessment and Removal of Pharmaceutical and Personal Care Products (PPCPs) in Source Water and Drinking Water}

Pharmaceuticals and personal care products (PPCPs) are used for a wide variety of applications for human and veterinary uses. Human pharmaceuticals of great interest include: analgesics, antibiotics and antimicrobials, anticonvulsant/antiepileptics, antidiabetics, antihystamines, antipsychotics, antidepressants, antianxiety drugs, beta-blockers ( $\beta$-blockers), cytostatics and antineoplastics, estrogens and hormonal compounds, lipid-regulators, stimulants, and X-ray contrast media. These compounds may be excreted directly or partially metabolized, resulting in their eventual passage into the environment. There are many routes to transport PPCPs into our natural water resources, such as improper disposal from individuals, residues from hospitals and veterinary drug use for animal farms (cattle, pigs, turkey, chicken, and others), residues from pharmaceutical factories (well defined and controlled), and so on. In the past decades, the issues of PPCPs in natural waters pertaining to the human usage, especially for antibiotics and steroids, were largely over looked. U.S. Geological Survey published a study in 2002 brought attention to PPCPs in water. Detectable of PPCPs were found in around 110 out of 139 susceptible streams in 30 states [10].

A recently published occurrence study [11] revealed that some
PPCPs were detected in untreated and treated water samples collected across Missouri, of which caffeine was detected at concentration of 224 $\mathrm{ng} / \mathrm{L}$. Even though the potential adverse effects on human by drinking water have attracted more and more attention, there is no specific water treatment plants equipped with PPCPs removal technology. It was reported that the average concentration of aspirin is $0.22 \mu \mathrm{g} / \mathrm{L}$ in some water treatment facilities in Germany, and the aspirin concentration can reach up to $13 \mu \mathrm{g} / \mathrm{L}$ in some water treatment facilities in Greek and Spain [12-16]. Benotti et al. [17] have screened a diverse group of pharmaceuticals, potential endocrine disrupting compounds (EDCs), and other unregulated organic contaminants from 19 U.S water utilities for 51 compounds, and 17 pharmaceuticals and 12 EDCs (Table 1). Due to the large variety of PPCPs that may have been transported to our natural water resources, the assessment and removal of PPCPs in source water or drinking water becomes important as there is uncertainty about their risk to the environment and human health.

Conventional detection methods, such as UV/Vis is absorption detection and fluorescence detection, cannot meet the needs for detecting $\mu \mathrm{g} / \mathrm{L}$ or $\mathrm{ng} / \mathrm{L}$ levels of PPCPs in water samples. Mass spectrometry (MS) hyphenated with other separation techniques have been widely used for PPCPs assessment in water samples. For example, determination of trace levels of PPCPs and EDCs has been accomplished by using gas chromatography-mass spectrometry(GC-MS) with derivatization [18]. The major limitations of GC are that samples must

\begin{tabular}{|c|c|c|c|c|c|c|c|}
\hline \multirow[b]{2}{*}{ Compounds } & \multirow[b]{2}{*}{ MRL } & \multicolumn{2}{|c|}{ Source } & \multicolumn{2}{|c|}{ Finished } & \multicolumn{2}{|c|}{ Distribution } \\
\hline & & $\max$ & med & $\max$ & med & $\max$ & med \\
\hline \multicolumn{8}{|l|}{ Pharmaceuticals } \\
\hline Atenolol & 0.25 & 36 & 2.3 & 18 & 1.2 & 0.84 & 0.47 \\
\hline Atorvastatin & 0.25 & 1.4 & 0.80 & $<\mathrm{MRL}$ & $<\mathrm{MRL}$ & $<\mathrm{MRL}$ & $<M R L$ \\
\hline Carbamazepine & 0.50 & 51 & 4.1 & 18 & 6.0 & 10 & 6.8 \\
\hline Diazepam & 0.25 & 0.47 & 0.43 & 0.33 & 0.33 & $<\mathrm{MRL}$ & $<M R L$ \\
\hline Diclofenac & 0.25 & 1.2 & 1.1 & $<\mathrm{MRL}$ & $<M R L$ & $<M R L$ & $<M R L$ \\
\hline Fluoxetine & 0.50 & 3.0 & 0.80 & 0.82 & 0.71 & 0.64 & 0.64 \\
\hline Gemfibrozil & 0.25 & 24 & 2.2 & 2.1 & 0.48 & 1.2 & 0.43 \\
\hline o-hydroxy atorvastatin & 0.50 & 1.2 & 0.70 & $<\mathrm{MRL}$ & $<M R L$ & $<\mathrm{MRL}$ & $<M R L$ \\
\hline$p$-hydroxy atorvastatin & 0.50 & 2.0 & 1.0 & $<\mathrm{MRL}$ & $<M R L$ & $<M R L$ & $<M R L$ \\
\hline Emprobamate & 0.25 & 73 & 8.2 & 42 & 5.7 & 40 & 5.2 \\
\hline Naproxen & 0.50 & 32 & 0.90 & $<\mathrm{MRL}$ & $<M R L$ & $<\mathrm{MRL}$ & $<M R L$ \\
\hline Norfluoxetine & 0.50 & $<M R L$ & $<\mathrm{MRL}$ & $<\mathrm{MRL}$ & $<M R L$ & 0.77 & 0.77 \\
\hline Phenytoin & 1.0 & 29 & 5.1 & 19 & 6.2 & 16 & 3.6 \\
\hline Risperidone & 2.5 & $<M R L$ & $<M R L$ & $<M R L$ & $<M R L$ & 2.9 & 2.9 \\
\hline Sulfamethoxazole & 0.25 & 110 & 12 & 3.0 & 0.39 & 0.32 & 0.32 \\
\hline Triclosan & 1.0 & 6.4 & 3.0 & 1.2 & 1.2 & $<M R L$ & $<\mathrm{MRL}$ \\
\hline Trimethoprim & 0.25 & 11 & 0.80 & $<M R L$ & $<M R L$ & $<M R L$ & $<M R L$ \\
\hline \multicolumn{8}{|c|}{ Known and potential EDCs } \\
\hline Atrazine & 0.25 & 870 & 32 & 870 & 49 & 930 & 50 \\
\hline $17 \beta$-estradiol & 0.50 & 17 & 17 & $<M R L$ & $<M R L$ & $<M R L$ & $<M R L$ \\
\hline Estrone & 0.20 & 0.90 & 0.30 & $<M R L$ & $<M R L$ & $<M R L$ & $<M R L$ \\
\hline 17a-ethynylestradiol & 1.0 & 1.4 & 1.4 & $<M R L$ & $<M R L$ & $<M R L$ & $<M R L$ \\
\hline Bisphenol A & 5.0 & 14 & 6.1 & 25 & 25 & $<\mathrm{MRL}$ & $<M R L$ \\
\hline Butylbenzyl phthalate & 50 & 54 & 53 & $<\mathrm{MRL}$ & $<\mathrm{MRL}$ & $<\mathrm{MRL}$ & $<\mathrm{MRL}$ \\
\hline Diethylhexyl phthalate & 120 & 170 & 150 & $<\mathrm{MRL}$ & $<\mathrm{MRL}$ & $<\mathrm{MRL}$ & $<M R L$ \\
\hline Galaxolide & 25 & 48 & 3 & 33 & 31 & $<M R L$ & $<M R L$ \\
\hline Linuron & 0.50 & 9.3 & 4.1 & 6.2 & 6.1 & $<M R L$ & $<M R L$ \\
\hline Nonylphenol & 80 & 130 & 100 & 100 & 93 & 110 & 97 \\
\hline Progesterone & 0.50 & 3.1 & 2.2 & 0.57 & 0.57 & $<M R L$ & $<\mathrm{MRL}$ \\
\hline Testosterone & 0.50 & 1.2 & 1.1 & $<\mathrm{MRL}$ & $<\mathrm{MRL}$ & $<\mathrm{MRL}$ & $<M R L$ \\
\hline
\end{tabular}

Table1: Method reporting limits (MRLs), maximum concentration (max), median concentration (med) of pharmaceuticals and EDCs in source water, finished water, and distribution systems. All concentrations are presented in $\mathrm{ng} / \mathrm{L}$. (The data were from Benotti et al. [17]). 
be volatile and thermally stable, which restrict this analytical technique to only certain PPCP compounds. Instead, liquid chromatographymass spectrometry (LC-MS) and liquid chromatography-tandem mass spectrometry (LC-MS/MS) have become popular analytical techniques for PPCPs analysis. A variety of LC-MS or LC-MS/MS methods have been developed and applied for simultaneous analysis of several or many PPCPs compounds in different types of water due to their high sensitivity, high accuracy, and high throughput [11,19-25]. Previously, UV-filtering compounds that are used in sunscreens, cosmetics, and other personal care products had mostly been measured using HPLC/ UV. In 2008, a new LC-MS/MS method for analysis of nine UV filter compounds in seawater, river water, and wastewater was developed with detection limits of 7-46 ng/L [26].

Recently, Wang et al. have developed a new HPLC-MS/MS method that can simultaneously quantify 16 pharmaceutical compounds in a single run with the method detection limits (MDLs) of $0.3-4.3 \mathrm{ng} / \mathrm{L}$ $[11,24]$. The method has been used to analyze PPCPs in different types of water samples, including: Mississippi River, Missouri River, lakes, reservoirs and deep wells, and 11 pharmaceuticals were identified, mostly in surface water samples. Due to the very low PPCP concentrations in water, pre-concentration using solid phase extraction (SPE) is often necessary to enrich the target PPCP compounds before HPLC-MS/MS analysis. Up to date nearly all SPE was performed by following US EPA method 1694 [27], but with different modifications according to the specific application. Even though, low recoveries for some of the PPCPs are unavoidable when large numbers of PPCPs are analyzed in a single sample because of the different retention efficiencies of PPCP compounds onto the cartridge. Therefore, isotope-labeled internal standards are often applied to the water sample preparation to account for the low recovery of some compounds and to enhance data accuracy $[11,27]$.

Removal of PPCPs has become a key concern in emerging contaminant control and drinking water protection. Until now, there is no comprehensive method to eliminate different categories of PPCPs from waters. The elimination of a specific analyte or a group of similar chemicals has been reported [16,24,28-37]. However, the removal efficiency may vary significantly among different PPCP compounds. For example, chlorination treatment can degradate sulfamethoxazole almost completely but it is not effective for carbamazepine [34]. Most water treatment plants utilize oxidation systems, such as free chlorine, ozone, and permanganate, monochloramine, or UV radiation during the water disinfection process. In addition, periodic powdered activated carbon (PAC) adsorption and two-stage lime softening are often used as part of the treatment process. Studies showed that both oxidation and PAC can remove some of the PPCP compounds [24,35-38]. Carballa et al. reported the removal of more than $80 \%$ sulfamethoxazole and natural estrogens, and more than $60 \%$ removal of galaxolide using ozone as the oxidant [39]. While efficient removal $(\approx 99 \%)$ was achieved by granular activated carbon (GAC), researchers have also investigated the removal efficiency of PPCPs in water by using reverse osmosis (RO) membrane filtration and nanofiltration (NF) with over $95 \%$ of removal [40]. Recently, Wang et al. [24] investigated the removal efficiencies of eight pharmaceuticals (caffeine, acetaminophen, carbamazepine, sulfamethoxazole, trimethoprim, erythromycin, lincomycin, and codeine) as a function of treatment approaches, types of disinfections (free chlorine, ozone, monochloramine, and permanganate). Their results showed that the oxidative removal of these pharmaceutical compounds varied significantly with different oxidation processes. Overall, chlorination was highly effective in the elimination of most of these pharmaceuticals and sample matrix, and $\mathrm{pH}$ caused notable differences in oxidation efficiency. Permanganate was also effective to decompose some pharmaceuticals. Ozone was a fast oxidizer but was very unstable. The ozone-oxidation was completed in about 2 minutes under the selected conditions. Chloramination was mostly ineffective in removal of all studied pharmaceuticals at typical dosage (3 $\mathrm{mg} / \mathrm{L})$ [24]. Parallel studies indifferent water matrices indicate that the oxidations preceded similarly but with a relatively slower rate in the surface water due to matrices effects. So far this work has shown that some oxidation systems may be useful in eliminating some of the PPCPs in water treatment facilities. The data on PPCP removal using Norit HDB PAC at normal dosage $(2 \mathrm{mg} / \mathrm{L})$ showed that most pharmaceuticals were not removed from the river water even when the equilibrium was reached after 24 hours. This comparison indicates that the sample matrix played an important role in the removal of pharmaceuticals from surface waters.

Ramsey et al. [41] explored the feasibility of using oxide nanomaterials and nano-activated carbon to remove sulfamethoxazole from natural and drinking water. Three different nano-materials (iron oxide, silicon oxide, and activated carbon) at four different contact time increments ( 30 minutes, 2 hours, 3 hours, and 24 hours) were used to investigate the removal efficiency of sulfamethoxazole. Iron oxide nanoparticles at 3 hour contact provided the best removal (100\%) for sulfamethoxazole in water. The data from that study provide important information for water treatment facilities that are looking for a cheap and easy way to remove this compound from natural water.

In conclusion, coagulation and filtration in conventional drinking water treatment processes are not adequate to remove PPCPs from the source water. The disinfectants used in water treatment, such as free chlorine, monochloramine, permanganate, ozone, UV, can only remove some of the PPCPs. Up to date; no single treatment process will completely remove all PPCPs from source water to non-detectable concentrations. Removal of PPCPs from natural waters and drinking waters is very challenging and more research needs to be done and new technologies need to be discovered or invented.

\section{Assessment and Removal of Emerging Disinfection Byproducts in Drinking Water}

In order to remove pathogenic microorganisms, water disinfection has been applied to the drinking water system since the early 1900s, and has become one of the most important treatments for drinking water [42]. However, the disinfectants commonly used may react with natural organic matter (NOM) and other chemicals (either natural or man-made products) present in the water to produce disinfection byproducts (DBPs), which may be a threat to human health. More than 600 DBPs have been identified so far [2]. Trihalomethanes (THMs), haloacetic acids (HAAs), bromate and chlorite are already regulated by the EPA. Perchlorate has been decided for regulation by EPA, but its limit level has not yet been agreed. Several groups of emerging DBPs have been reported, including halonitromethanes, N-nitrosamines, haloacetonitriles, haloamides, halofuranones, among others.

Biannual periodic reviews on emerging drinking water contaminants, including emerging DBPs, have been published by Richardson [2-8]. In this review, only the most recent publications will be included. One of the most actively studied DBPs is the $\mathrm{N}$-nitrosamine group because of the high toxicity of these compounds. The most frequently detected $\mathrm{N}$-nitrosamine in drinking water is $\mathrm{N}$-nitrosodimethylamine (NDMA). It was discovered initially in chlorinated drinking waters from Ontario, Canada [43]. According to surveys conducted across Asia and the Americas, NDMA is present at 
the low ng/L level in both source water (surface and ground water) and drinking water [44-46]. A specific review on nitrosamines summarized the formation of NDMA and related analogues [47]. Chloramination with a high concentration of $\mathrm{N}$-nitrosamine precursors present in water could result in elevated NDMA formation. Recently, Wang and Cheng et al. $[48,49]$ developed a fast and sensitive HPLC-MS/MS method for simultaneous quantitative analysis of nine $\mathrm{N}$-nitrosamines and four precursors in drinking water. Their MDLs in water ranged from 0.05 $\mu \mathrm{g} / \mathrm{L}$ to $5 \mu \mathrm{g} / \mathrm{L}$ without any preconcentration procedures. Wang and Ren et al. [46] developed a method to analyze nine nitrosamines with a MDL ranged from $0.2-0.9 \mathrm{ng} / \mathrm{L}$ for the source water samples and 0.1$0.7 \mathrm{ng} / \mathrm{L}$ for the finished water samples.

Since DBPs are generally present as a complex mixture in the drinking water treatment system at concentrations from low ng/L (ppt) to $\mu \mathrm{g} / \mathrm{L}$ (ppb) levels, it makes separation and detection of DBPs more challenging. Several reviews on the detection of DBPs in drinking water have been published [50-52]. For the DBPs with low molecular mass, thermally stable, and volatile or semi-volatile characteristics, GC methods have played an essential role in the analytical measurements of these compounds. Electron capture detector (ECD) is one of the most commonly used detectors in GC for analysis of compounds with electron-withdrawing groups. Pre-concentrate preparation methods such as SPE, liquid-liquid extraction, and solid phase micro extraction (SPME) are generally used to concentrate the analytes. Because of the large GC-MS database library existing for many organic compounds, which make identification of unknown compounds much easier, GC-MS has also become a key technique for DBP discovery and quantification. Over the last 25 years, hundreds of DBPs have been identified, mostly through the use of GC-MS. However, the use of GCMS is limited or of no use when the target DBPs have high molecular mass, such as over $1000 \mathrm{Da}$ after derivatization, are non-volatile or very polar (e.g. ionic DBPs). One way to overcome this limitation is by derivatizing the analytes to make them volatile, but this can be difficult for some compounds. Therefore, the applications of HPLCMS or HPLC-MS/MS provide a better way to analyze DBPs with high molecular weight and/or high polarity in water samples without derivatization.

Ion chromatography-inductively coupled plasma-mass spectrometry (IC-ICP-MS) is also suitable for the analysis of some DBPs such as iodoacetic acids, bromoacetic acids, and bromate. Recently, Shi et al. have developed a new rapid and sensitive method for simultaneous analysis of six brominated and four iodinated acetic acids, bromate, iodate, bromide, and iodide using IC-ICP-MS [53]. The method detection limits (MDLs) in natural water ranged from 0.33 to $0.72 \mu \mathrm{g} / \mathrm{L}$ for iodine species, and from 1.36 to $3.28 \mu \mathrm{g} / \mathrm{L}$ for bromine species.

Because of the arising concern for human health risks of DBPs in drinking water, control and removal of DBPs are necessary. One commonly used approach is to prevent the formation of DBPs in the first place by removal of the DBP precursors, in which coagulation and ion exchange could be used [54]. Adsorption by GAC and PAC has also been used to remove some of the DBPs and their precursors from the water. Recently, Cheng et al. [49] have examined three different types of PACs, namely bituminous coal-based WPH, lignite coal-based Hydro Darco B (HDB), and wood-based Aqua Nuchar (AN), for their efficiency in removing $\mathrm{N}$-nitrosamines at three $\mathrm{pH}$ values from both Milli-Q water and natural water. WPH was the most effective PAC at removing most $\mathrm{N}$-nitrosamines at typical dosages and contact times, although a pH-dependent trend was observed, with lesser removal at higher $\mathrm{pH}$. NOM in surface waters had little effect on the sorption of the $\mathrm{N}$-nitrosamines. AN and HDB demonstrated relatively low adsorptive capacity for the studied $\mathrm{N}$-nitrosamines at all $\mathrm{pH}$ levels, even with dosages of up to $10 \mathrm{mg} / \mathrm{L}$ in both DI and natural water. Although nitrosamines formation during water treatment sometimes occurred in the distribution systems, these results still have significant implications whenever there are high nitrosamine levels in the water treatment plant influents, especially those that are fed from upstream wastewater discharges. In addition, removal of nitrosamines by nanomaterials has been explored. Wang et al. [48] have tested three different types of activated carbon nano-particles (NPs) from bamboo, charcoal, and coconut shell as raw materials. The removal experiments were carried out at two different $\mathrm{pH}$ (6.6 and 8.6). Coconut shell-based activated carbon NPs had better removal efficiency for this group of compounds than the other two activated carbon NPs. The removal efficiency in reagent water was as high as $50 \%$, with a typical dosage of 2 ppm activated carbon NPs, at a typical contact time of 4 hours. In pre-filtrated river water, the removal efficiency was a little lower due to competition from NOM. No significant differences between the two selected $\mathrm{pH}$ values were observed.

Advanced oxidation processes (AOPs) have also been suggested as appropriate techniques to remove the NOM from drinking water [55]. Other techniques, such as membrane filtration and ion exchange are also applicable options [56]. Carbonized electro spun nano fibrous membranes have shown effective removal of some DBPs removal from drinking water. It has also been reported that anion exchange can effectively remove DOM from solution and reduce DBP formation during chlorination [57]. While effort has been made to control and remove currently known DBPs, we are still facing great challenges on numerous unknown DBPs. Thus, more research need to be conducted and sensitive analytical methods need to be developed to monitor and effectively remove DBPs from drinking water.

\section{Assessment and Removal of Cyanotoxins in Source Water and Drinking Water}

Known as blue-green algae, Cyanobacteria are photosynthetic microorganisms found in lakes, streams and ponds. There are thousands of cyanobacteria species about half of which produce toxins. A variety of cyanobacteria and their toxins have been identified and their occurrence has been reported in fresh, brackish and marine waters all over the world. The presence of cyanotoxins in surface or drinking water may cause serious health risks to humans and animals. For example, hepatotoxins affect the liver and kidney, neurotoxins affect the central nervous system, and dermatotoxins, which are skin irritants, are capable of causing both acute and chronic illnesses. Based on toxicological, epidemiology and occurrence studies, the EPA Office of Ground Water and Drinking Water has restricted its efforts to 3 of the over 80 variants of cyanotoxins reported, recommending that microcystinscongeners LR, YR, RR and LA, and cylindrospermopsinbe placed on the Unregulated Contaminant Monitoring Rule (UCMR) [58-70]. Table 2 summarizes the effectiveness of various types of treatment for removal of intact cyanobacteria cells and treatment processes that are effective in removing extracellular dissolved toxins of several of the most important cyanobacteria.

Among the major cyanotoxins, saxitoxins are a large family, better known as the paralytic shellfish poisoning toxins. These toxins have comparable toxicity to some toxigenic marine dinoflagellates that accumulate in shellfish feeding on those algae. Saxitoxins have been reported in freshwater cyanobacteria such as Aphanizomenon spp. and 
Citation: Shi H, Cheng X, Wu Q, Mu R, Ma Y (2012) Assessment and Removal of Emerging Water Contaminants. J Environ Anal Toxicol S2:003. doi:10.4172/2161-0525.S2-003

Page 5 of 14

\begin{tabular}{|c|c|}
\hline Treatment Process & Relative Effectiveness \\
\hline \multicolumn{2}{|l|}{$\begin{array}{l}\text { Intracellular Cyanotoxins Removal } \\
\text { (Intact Cells) }\end{array}$} \\
\hline Pretreatment oxidation & Avoid pre-oxidation because often lyses cyanobacteria cells releasing the cyanotoxin to the water column. \\
\hline Coagulation/Sedimentation/Filtration & $\begin{array}{l}\text { Effective for the removal of intracellular toxins when cells accumulated in sludge are isolated from the plant and the sludge } \\
\text { is not returned to supply after sludge separation. }\end{array}$ \\
\hline Membranes & $\begin{array}{l}\text { Study data is scarce; it is assumed that membranes would be effective for removal of intracellular cyanotoxins. Microfiltration } \\
\text { and ultrafiltration are effective when cells are not allowed to accumulate on membranes for long periods of time. }\end{array}$ \\
\hline Flotation & $\begin{array}{l}\text { Flotation processes, such as Dissolved Air Flotation (DAF), are effective for removal of intracellular cyanotoxins since many } \\
\text { of the toxin-forming cyanobacterial are buoyant. }\end{array}$ \\
\hline Oxidation Processes & Avoid because often lyses cyanobacterial cells releasing the cyanotoxin to the water column. \\
\hline \multicolumn{2}{|l|}{ Extracellular Cyanotoxins Removal } \\
\hline Membranes & $\begin{array}{l}\text { Depends on the material, membrane pore size distribution, and water quality. Nanofiltration and ultrafiltration are likely } \\
\text { effective in removing extracellular microcystin. Reverse osmosis filtration would likely only be applicable for removal of } \\
\text { some extracellular cyanotoxins like cylindrospermopsin. Cell lysis is highly likely. Further research is needed to characterize } \\
\text { performance. }\end{array}$ \\
\hline Potassium Permanganate & Effective for oxidizing microcystins and anatoxins. Further research is needed for cylindrospermopsin. \\
\hline Ozone & Very effective for oxidizing extracellular microcystins, anatoxin-a and cylindrospermopsin. \\
\hline Chloramines & Not effective \\
\hline Chlorine dioxide & Not effective with doses used in drinking water treatment. \\
\hline Chlorination & Effective for oxidation extracellular cyanotoxins as long as the pH is below 8, ineffective for anatoxin-a. \\
\hline UV Radiation & Effective of degrading microcystins and cylindrospermopsin but at impractically high doses. \\
\hline Activated Carbon & $\begin{array}{l}\text { PAC: Most types are generally effective for removal of microcystin, anatoxin-a and cylindrospermopsin, especially wood- } \\
\text { based activated carbon. } \\
\text { GAC: Effective for microcystins but less effective for anatoxin-a and cylindrespermopsins. }\end{array}$ \\
\hline
\end{tabular}

Table 2: Summary of treatment process and effectiveness for removal of intact cyanobacteria cells and extracellular dissolved toxins. Adapted with permission from EPA report [71].

Lyngbya wollel [71,72]. Cylindrospermopsin was firstly identified in the species Cylindrospermopsis raciborskii which have begun to rapidly increase and dominate some Florida water bodies since 1997. This cytotoxic alkaloid is highly water soluble and stable to relative extremes of temperature and $\mathrm{pH}$ [72-77]. Microcystins are the most abundant cyanotoxins which can be produced by various cyanobacteria such as Microcystis, Anabaena and Nostoc. Microcystins have been surveyed in many countries including Australia, Canada, China, Holland, and US, and the toxin levels were reported from 0.3 to $80 \mu \mathrm{g} / \mathrm{L}$, of which MCLR is the most common and toxic, making up $45.5 \%$ to $99.8 \%$ of total micro cystins found in natural waters $[59,67,73]$.

Continually advancing technology fulfills the immediate need for both screening and confirmatory methods for the cyanotoxins analyses. Traditionally, different analytical methods such as UV detection (for toxins with UV chromophore), fluorescence detection for saxitoxins [78], GC-MS for anatoxin, static Fast Atom Bombardment mass spectrometry [79] and on-line Continuous flow-Fast Atom Bombardment mass spectrometry detection for microcystins $[80,81]$, were required for studying different classes of cyanobacterial toxin. Mass spectrometry, unlike UV spectroscopy, has the advantage that it can handle compounds lacking the UV chromophore. Furthermore GC-MS is applicable to study anatoxin-a, although samples have to be derivatized before analysis [82]. The most sensitive technique currently used for the analysis of trace-level concentrations in water samples involves liquid chromatography-mass spectrometry, specifically liquid chromatography - tandem mass spectrometry (LC-MS/MS), which has been widely applied in environmental analysis [83,84]. A range of LC-MS/MS methods for cyanotoxins have been developed [85-88], and most of these methods are dependent on sample cleanup methods. Bogialli et al. firstly reported a SPE-LC-MS/MS method for measuring microcystins and cylindrospermopsin with limits of quantification within 2-9 nl/L range [87], and one year later Hiller et al. developed a method in precursor ion mode by LC-MS/MS to detect the maximum number of cyanobacterial toxins from different toxin groups in a single chromatographic separation, and a detection limit of $9 \mathrm{pg}$ for cylindrospermopsin could be achieved [88]. Very recently, Cheng et al. developed a fast and easy method for quantitative analysis of nine major cyanotoxins using LC/MS/MS without sample cleanup processes [89].

Due to increasing occurrence and high toxicity, effective treatments strategies are needed to prevent cyanotoxins inform reaching the drinking water. Conventional treatments commonly used include both chemical and physical procedures, such as various oxidants, UV irradiation or coagulation. Experimental and full-scale studies for removal of cyanobacteria using membranes are scarce. In general, micro- and ultra-filtration membranes could be expected to remove cyanobacterial cells effectively [90-92]. The treatments mentioned above will not remove extracellular or dissolved toxin to a significant extent. Most of the microcystins are well removed by activated carbon $[93,94]$, the exception being MC-LA, but for other Microcystins wood-based chemically activated carbon is the most effective treatment. GAC filtration displays a limited lifetime for all toxins, due to eventual saturation of the filters. In addition to filtration, dissolved microcystins have been removed by some reverse osmosis and nanofiltration membranes [95,96]. Chlorination and ozonation are also effective for removal of microcystins. A residual of at least $0.3 \mathrm{mg} / \mathrm{L}$ of ozone for 5 minutes will be sufficient for removing all the most common microcystins [92,97-100]. Cheng et al. examined several oxidative and UV irradiation disinfection treatments for removal cylindrospermopsin and its source micro-organisms, Cylindrospermopsis raciborskii [82]. Ozone and free chlorine were highly effective at the removal both of cylindrospermopsin and of Cylindrospermopsis raciborskii. Chlorinedioxide, monochloramine, permanganate, and UV irradiation at typical water treatment dosages were all ineffective at removing cylindrospermopsin. Chlorinedioxide, monochloramine, and permanganate were each only capable of partial inactivation of Cylindrospermopsis raciborskii. This information provides a basis for removal of both Cylindrospermopsis raciborskii 
and cylindrospermopsin in water treatment plants. An interesting argument was discussed in a recently published work by Shi et al. on the impacts of $\mathrm{pH}$ as well as NOM concentrations on the adsorptive efficiency of PAC for saxitoxin treatment, which reinforce the critical role of PAC sorption performance on water quality [101].

\section{Assessment and Removal of Pesticides and Their Degradation Products in Source and Drinking Water}

The widespread use of insecticides, fungicides and herbicides over the past 60 years has led to increased occurrence of pesticide residues in all types of water resources, including drinking water and water for recreational purposes. Degradation of these pesticide residues may occur in environmental waters by natural processes of hydrolysis, photolysis and biological remediation carried out in situ [102]. In addition to these natural processes, remediation through different treatments includes chemical oxidation, photolysis with UV, hydrolysis at acidic or alkaline $\mathrm{pH}$, biodegradation by microbes and phyto-remediation [103-110]. The degradates of these pesticides in a wide variety of water supplies have also been detected. Toxicity of degradates can in some cases be equal or greater than that of the parent compounds [111-113]. Thus, the investigation of pesticide degradation by-products is an emerging research area in the field of water quality.

A number of analytical methods have been developed for detecting the large variety of pesticides residues found in waters. HPLC-MS, HPLC-MS/MS, GC-MS, and GC-MS/MS have been commonly used for analysis of pesticides and their degradation by-products [114123], either with direct sample injection, or after SPE or liquid-liquid extraction (LLE) [114]. LC-MS/MS is currently becoming the most powerful technique because of its excellent sensitivity, rapid analysis, and little sample preparation compared with previous GC and HPLC analytical techniques. Recent developments of ultra-pressure liquid chromatography (UPLC) and enhanced ion-trap function of MS will further advanced the UPLC-MS/MS technology for its applications in water research and many other fields. The recent availability of LC columns with smaller particle size also contributes to higher resolution and speed of analysis for both LC/MS and UPLC techniques. A number of quantification and identification methods using LC-MS/ MS have been developed and applied to analysis of pesticides and their degradation products in drinking water and source water [84,115117,121-125]. The methods have been used for occurrence studies, degradant identifications, reaction pathway elucidation, and kinetic investigation. It is anticipated that LC-MS/MS technique will continue to play a most important role in drinking water and source water research in the near future.

Screening studies of widely used pesticide and their degradants in drinking water and source water have been conducted under general water treatment conditions. One such comprehensive study focused on the reactivity of a set of 62 pesticides from 14 different classes: acid compounds, amides, carbamate insecticides, dinitroanilines, isoxazoles, organochlorins, organophosphorus insecticides, phthalate, pyrazole, triazines, urea herbicides, thiazole, triazine, and pyrethroids $[115,117,125]$. The general disinfection treatment methods in this study included oxidation by six oxidants (free chlorine, monochloramine, chlorine dioxide, hydrogen peroxide, ozone, and permanganate), photodegradation by $\mathrm{UV}_{254}$, and hydrolysis under different $\mathrm{pH}(2,7$, and 12). Pesticides and their degradates were analyzed by LC-MS, LCMS/MS, and GC-ECD, with methods having MDLs at ng/L levels. The MDLs by LC-MS via direct injection of samples were in the ranges of $16 \mathrm{ng} / \mathrm{L}$ to $493 \mathrm{ng} / \mathrm{L}$, and MDLs by GC-ECD were $12 \mathrm{ng} / \mathrm{L}$ to $139 \mathrm{ng} / \mathrm{L}$ after LLE. Many pesticides were found to be reactive via hydrolysis and/ or chlorination and ozonation under typical drinking water treatment conditions, less reactive with chlorine dioxide, monochloramine, hydrogen peroxide, and $\mathrm{UV}_{254}$. Forty percent of the pesticides were highly reactive with one or more oxidants, while $60 \%$ were at least moderately reactive. Organophosphorus and carbamate insecticides/ herbicides were the most reactive classes overall, while others were found less reactive.

Sulfonic acid (SA) and oxanilic acid (OA) degradation products of herbicides were shown to be more persistent and mobile than their parent compounds [126-129]. A screening study of herbicide degradation byproducts of metolachlor, alachlor, acetochlor, and propachlor in a variety of water treatment plants has been performed by using a very rapid and sensitive LC-MS/MS method developed by Cheng et al. [117]. Eight ESA and OA major degradation products were analyzed at detection limits of 40-50 ng/L, the lowest detection limited reported without sample pre-concentration. Screening of these degradation products from both source water and treated water of 34 water treatment facilities in Missouri was conducted for both winter and summer seasons. The water resources include river water, lake water, reservoir water, and underground water. All the herbicide degradants were not detectable in the water collected in winter season while some degradants were detected in the water collected during summer season, at concentration range from none detectable to 60 ng/L. Missouri River and Mississippi River water resources were found to have more herbicide degradants than the other water resources tested. Another comprehensive full-scale study was conducted for atrazine, simazine, and propazine [130]. About 900 paired source water and treated drinking water samples were analyzed by GCMS method for the parents and the degradants of these herbicides. Atrazine concentrations were generally below the established $3 \mu \mathrm{g} / \mathrm{L}$ maximum contaminant level (MCL) and that simazine and propazine concentrations were generally non-detectable. Degradant chloro-striazine was detected in both source water and already treated water. PAC is effective ( $95 \%$ removal) for the removal of atrazine and the degradant [131].

The organophosphorus insecticide dyfonate (active ingredient fonofos) is most widely used to control Lepidoptera and all other insect pests. Like most organophosphorus compounds, high hydrolysis rate was observed during screening studies $[116,118,126]$. A comprehensive investigation on the hydrolysis of dyfonate and its degradation products in alkaline aqueous solution was conducted by Wang et al. [122]. The hydrolysis product of dyfonate at elevated $\mathrm{pH}(10,11$, and 12) was investigated in phosphate buffered water over the course of 7 days. Two major hydrolysis degradation products, thiophenol and phenyl disulfide, were separated, identified, and quantified using LC/MS/MS, HPLC-PDA and GC-MS methods. Dyfonate hydrolysis products were reported highly $\mathrm{pH}$ dependent. The transformation pathways and $\mathrm{pH}$ effect were suggested as the following illustration (Figure 1).

The disinfection byproducts of dyfonate via various oxidation treatments including free chlorine $(\mathrm{FC})$, hydrogen peroxide $\left(\mathrm{H}_{2} \mathrm{O}\right.$ 2), monochloroamine (MCA), chlorine dioxide $\left(\mathrm{ClO}_{2}\right)$, ozone, and permanganate were also investigated by the same group of researchers [122]. Dyfonate oxygen analog (phosphonothioic acid) was identified as the primary oxidation byproduct by $\mathrm{FC}$, ozone, MCA, and $\mathrm{H}_{2} \mathrm{O}$ treatment in the following pathway, while no oxidation byproduct was detected in the $\mathrm{ClO}_{2}$ and permanganate oxidation system. It was suggested that this degradant is more difficult to remove from water than the parent compound dyfonate. However, the degradant was less toxic. 


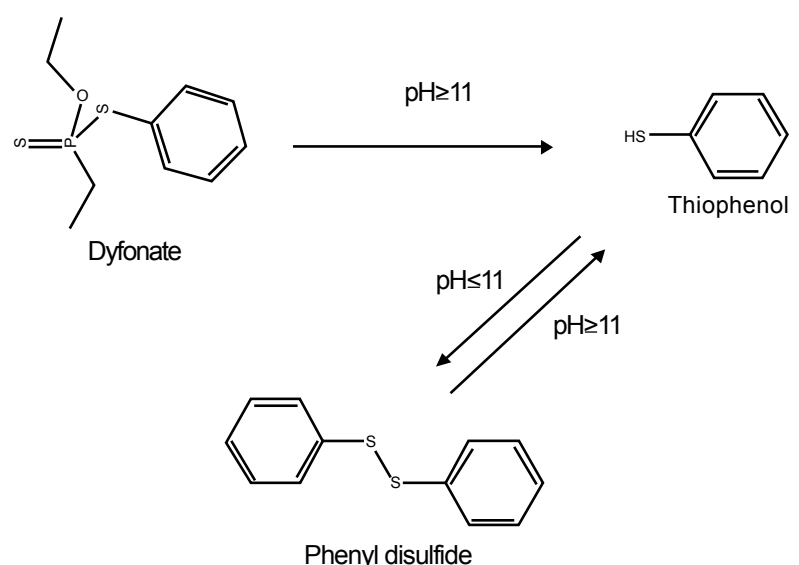

Figure 1: Proposed pathways of the degradation of dyfonate in alkaline aqueous solution. (Adapted from, Wang et al. [123])

Fipronil is a phenylpyrazole insecticide, increasingly being used in place of organophosphates, pyrethroids, carbamates, and many cyclodienes. However, fipronil is more persistent in soil and water than the former compounds [132], and this poses a problem for water quality. The oxidation and degradation of fipronil during drinking water treatment has been investigated under various water oxidation conditions including FC, $\mathrm{MCA}, \mathrm{ClO}_{2}$, and $\mathrm{MnO}_{4}^{-}$, and the kinetic rate of fipronil and fipronilsulfone were determined [117]. Fipronil was degraded quickly by treatment with $\mathrm{FC}, \mathrm{ClO}_{2}$, and $\mathrm{MnO}_{4}$. However, the common reported degradates (including fipronilsulfone, fipronil sulfide, and fipronildesulfinyl, all of which are as toxic as the parent compound) were not detected after treatment with $\mathrm{FC}$ and $\mathrm{ClO}_{2}$, by using the LC-MS analytical method. One degradant fipronilsulfone was identified from the treatment of $\mathrm{MnO}_{4}^{-}$. Oxidation of fipronil by MCA was very slow or insignificant in the tested period of seventy minutes. The half-life of the fipronil degradation by MCA was $3.1 \times 10^{5} \mathrm{~min}$ at $\mathrm{pH} 6.6$ and $3.1 \times 10^{5} \mathrm{~min}$ at $\mathrm{pH} 8.6$, respectively. Half-life and reaction rate constants of the degradation of fipronil at $\mathrm{pH} 6.6$ and 8.6 for tested oxidants have been determined and the reaction rates are higher under higher $\mathrm{pH}$ from all the oxidation treatments.

Aldicarb is a carbamate class pesticide. As a result of widespread usage, aldicarb and its metabolites have been detected in drinking water systems in several countries, and cases of human poisoning have occurred [133]. Ozone and free chlorine treatments were investigated for degradation of aldicarb in 1990s [110,134]. Recently, a systematic study of aldicarb and its metabolites was conducted involving treatment with various oxidants in water, with analysis by HPLCMS and HPLC-UV [124]. Free chlorine, high-dosage UV radiation and permanganate were very reactive with aldicarb, whereas chlorine dioxide showed weak oxidation. Aldicarb sulfoxide was identified as a major degradation product of aldicarb by oxidation with FC, MCA, ozone, and hydrogen peroxide, while aldicarb sulfone was identified as an oxidation byproduct of both aldicarb and aldicarb sulfoxide by permanganate treatment. Aldicarb sulfone was found to degrade further to N-chloro-aldicarb sulfone by FC. Degradation pathways of aldicarb by different oxidants were proposed as shown in Figure 2. All degradates are even more toxic than the parent insecticide [135,136]. Based on this systematic study, if aldicarb was indeed transported into the source water, aldicarb sulfoxide would be the major potential aldicarb degradates in drinking water after FC or MCA treatment, which are the two majorly used oxidation systems in drinking water treatment plants.

Molinate is a thiocarbamate herbicide widely used in agriculture. Occurrence studies indicated that molinate contamination exists in many natural water systems including river waters [137], rain water, ground water, and surface waters [138-141]. The removal efficiency of molinate by various oxidants and identification of the degradates of molinate in drinking water system have been systematically investigated using LC-MS/MS [121]. The oxidants tested were FC, MCA, $\mathrm{ClO}_{2}$, permanganate, $\mathrm{H}_{2} \mathrm{O}_{2}$, ozone; and UV radiation. Research has showed that only FC and ozone can oxidize molinate, while other oxidants and UV did not show significant removal of this herbicide. A kinetic study showed that the degradation of molinate with free chlorine treatment was extremely fast [121]. Hexahydro-1-H-azepane1-carboxylic acid was identified as the major degradate of molinate after treatment with free chlorine and ozone. This degradant is more resistant to free chlorine in the same treatment. A possible degradation reaction of molinate was suggested in that study.

Diazinon is an organophosphorus insecticide that has been used for many years in agriculture. It is highly reactive under typical oxidation treatment conditions. An in-depth study of diazinon oxidation and hydrolysis degradations were also conducted under such conditions [126] as FC, $\mathrm{MCA}, \mathrm{O}_{3}, \mathrm{ClO}_{2}, \mathrm{H}_{2} \mathrm{O}_{2}$, and $\mathrm{UV}_{254}$. Diazinon can be rapidly converted to the active diazoxon and the degradate IPMP during FC and ozone disinfection (Figure 3). Both compounds are stable to further FC oxidation at typical water disinfection conditions, but the oxon form is more toxic than the parent compound. In fact, it is the active insecticidal compound, which inhibits acetylcholinesterase in all animals [142]. On the other hand, both compounds are labile to further oxidation by $\mathrm{O}_{3}$, and, hence, they may be further converted to unknown degradates during ozonation.

Dimethenamid, a chloroacetamide herbicide used to control grasses was also studied in detail under drinking water treatment conditions [126]. Among the disinfection treatments by FC, MCA, $\mathrm{ClO}_{2}, \mathrm{H}_{2} \mathrm{O}_{2}, \mathrm{UV}_{25}, \mathrm{O}_{3}$, and $\mathrm{MnO}_{4}$, dimethenamid can only be degraded by $\mathrm{FC}$ and $\mathrm{O}_{3}$, while the other oxidants did not show significant removal of dimethenamid. Chloro-dimethenamid was identified as the major product of FC treatment, while different degradant was found by ozonation (Figure 4). All of the other oxidants had low levels of dimethenamid removal and no degradation products were detected.

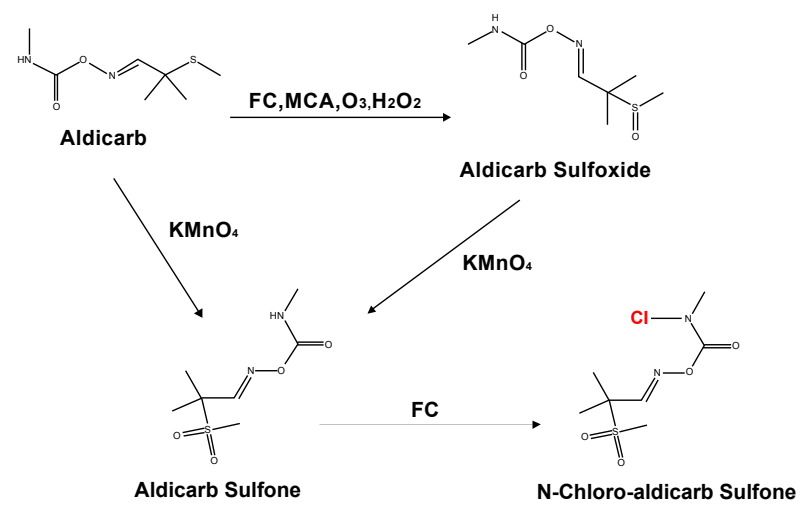

Figure 2: Proposed degradation pathways of aldicarb by various oxidants (Adapted from Wang et al. [124]). 


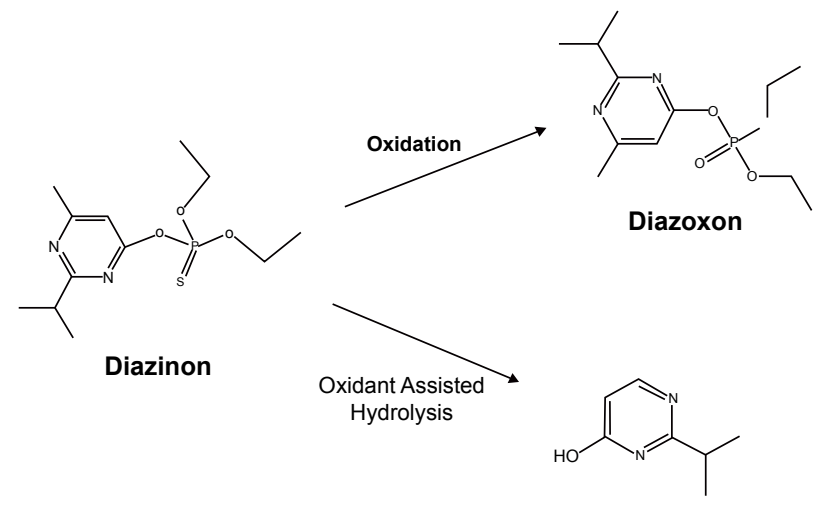

Figure 3: Proposed diazinon oxidation and/or hydrolysis degradates. (Adapted from Chamberlain E et al. [126]).<smiles>COCC(C)N(C(=O)CCl)c1c(C)sc(Cl)c1C</smiles>

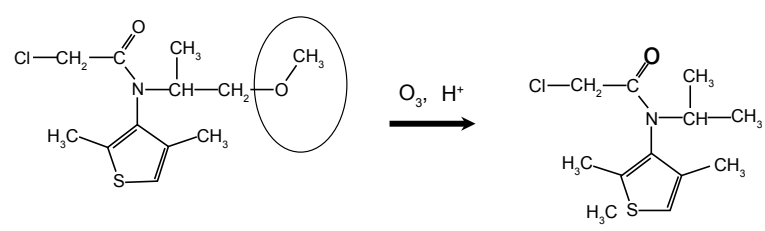

Figure 4: Proposed dimethenamid oxidation degradates by FC and ozone (Adapted from Chamberlain E et al. [126]).

Fungicides are widely used in agriculture to prevent the outbreak of persistent, significant plant diseases and also in several biocidal product types for material protection (treatment of wood, concrete, paints, and roofs) [143]. There are more than 67000 pesticide products currently registered for use in the United States, in which over 3600 are used for fungal diseases [144]. An estimate of 7-24\% of the losses in yields to commodity crops such as potatoes worldwide was caused by fungal pathogens in 2001-2003 [145]. Serious concerns have been raised about the potential harmful effects of fungicides on aquatic ecosystems due to their persistence in soil and water [146] due to their stability towards hydrolytic, photolytic and biological degradation as well as their endocrine disrupting properties [147]. Pyrimethanil, an anilino-pyrimidine fungicide, has been classified as persistent organic environmental pollutant [148] because of its high chemical and photochemical stability, and low biodegradability. Reilly et al. [147] has conducted occurrence study in three targeted use areas and some fungicides have been detected (Table 3).

Several sensitive analytical techniques have been developed to quantify fungicides in variety of environmental matrices, such as surface water, wastewater, sediment, sludge, and soil. A very concise review has covered some of the chromatographic determination of fungicides in biological and environmental matrices [149]. An ultrahigh-performance liquid chromatography-tandem mass spectrometry (UHPLC-MS/MS) has been well developed to 19 biocides with quantification limits ranging from $0.01-8 \mathrm{ng} / \mathrm{L}$ and with a recovery range of $70-120 \%$ based on the matrices [150]. The method has been used to study the occurrence of these compounds in influent samples and 16 targeted compounds have been detected in the concentration range of $0.4-372 \mathrm{ng} / \mathrm{L}$ [150]. In addition, HPLC methods with UV detection have also been developed for determination of fungicides $[151,152]$. The methods have been used to determine benomyl, carbendazim, 2-aminobenzimidazole (2-AB), thiabendazole, and iprodione (I) in surface water. The detection limit ranges from 1-4 $\mu \mathrm{g} / \mathrm{L}$ without preconcentration. By using on-line preconcentration, the detection limit for iprodione (I) can reach to $0.02 \mu \mathrm{g} / \mathrm{L}$.

GC-MS methods for quantitative analysis of fungicide compounds are still powerful methods if the compounds are thermally stable and volatile. Reilly et al. [147] has developed an GC- ion trap mass spectrometry (GC/IT-MS) method for occurrence study of selected fungicides in surface and groundwater, and the method detection limits (MDLs) for all compounds in water ranged from 0.9 to 12.1 ng/L. Takagaki et al. [152] has developed a rapid and sensitive GC-MS method for analysis of dithiocarbamate fungicides (mancozeb, maneb, and polycarbamate) in environmental water samples with solid-phase micro-extraction. The linearity of the working curves was obtained in the concentration range from $0.3 \mu \mathrm{g} / \mathrm{L}$ to $10.0 \mu \mathrm{g} / \mathrm{L}$ for all compounds.

Several methods have been reported to remove fungicide. Papinutti et al. [153] have reported a novel way to remove triphenylmethane dye malachite green (MG), commonly used as fungicide, by using wheat bran (WB). The study results showed that the equilibrium was attained after $40 \mathrm{~min}$ of contact time $(24 \mathrm{mg} / \mathrm{g}$ dry $\mathrm{WB})$ and the maximum adsorption of dye occurred at $\mathrm{pH}$ range $7-9$, where the amount of dye removed was nearly $90 \%$. A phytoremediation technique of fungicides by aquatic macrophytes has also been reported [154]. The rate of removal of 2 fungicides (dimethomorph and pyrimethanil) from water by 5 macrophyte species (L. minor, S. polyrhiza, C. aquatica, C. palustris and E. canadensis) was assessed and the maximum removal rate during the 4-day test period was $48 \mu \mathrm{g} / \mathrm{g}$ fresh wt. (FW) for dimethomorph and $33 \mu \mathrm{g} / \mathrm{g}$ FW for pyrimethanil. Physical treatment to remove some fungicides have also been reported [155] by using primary (mech.), secondary (activated sludge), and tertiary (sand filtration and chlorination) treatments. The results showed that all the azole fungicides and pyrimethanil showed relatively low removal efficiencies after secondary and tertiary treatments. Average removal rates of the fungicides after secondary treatment ranged from $31 \%$ for pyrimethanil to $65 \%$ for triadimefon. The average overall removal efficiencies after tertiary treatment ranged from $46 \%$ for pyrimethanil to $93 \%$ for triadimefon.

Neonicotinoids are a group of insecticides that have been used extensively as commercial insecticide. Imidacloprid, the representative of the first generation neonicotinoid insecticides, was patented in 1985 by Bayer and was placed on the market in 1991. Imidacloprid is selective toxicity for insects over vertebrates [156] and it is the highest selling insecticide worldwide used to control insects on crops or for seed treatment as well as veterinary medicine against parasites in dogs and cats. Imidacloprid has high solubility in water (580 ppm), is hydrolytically stable, and has long aerobic soil half-life (520 days). Based on the previous studies, the common transformation product of two neonicotinoids, Imidacloprid [157-159] and acetamiprid [160] is 
Citation: Shi H, Cheng X, Wu Q, Mu R, Ma Y (2012) Assessment and Removal of Emerging Water Contaminants. J Environ Anal Toxicol S2:003. doi:10.4172/2161-0525.S2-003

Page 9 of 14

\begin{tabular}{|c|c|c|c|c|c|c|c|c|}
\hline & \multirow[b]{2}{*}{ Type } & \multirow{2}{*}{\begin{tabular}{|l} 
Total $(\mathrm{N}=\mathbf{7 2})$ \\
Frequency $(\%)$
\end{tabular}} & \multicolumn{3}{|c|}{ Groundwater $(\mathrm{N}=12)$} & \multicolumn{3}{|c|}{ Surface water $(\mathrm{N}=60)$} \\
\hline & & & Frequency (\%) & Median (ngL-1) & Maximum $\left(\mathrm{ngL}^{-1}\right)$ & Frequency (\%) & Median (ngL-1) & Maximum $\left(\mathrm{ngL}^{-1}\right)$ \\
\hline Boscalid & $\mathrm{F}$ & 72 & 58 & 16.0 & 2120 & 75 & 22.6 & 109 \\
\hline Metolachlor & $\mathrm{H}$ & 57 & 33 & 68.3 & 120 & 62 & 37.0 & 1750 \\
\hline Atrazine & $\mathrm{H}$ & 55 & 67 & 8.0 & 33.5 & 53 & 14.7 & 132 \\
\hline Azoxystrobin & $\mathrm{F}$ & 51 & 17 & $(0.8)$ & $(0.9)$ & 58 & 30.6 & 59.8 \\
\hline Chlorothalonil & $\mathrm{F}$ & 40 & 50 & $(0.5)$ & 8.7 & 35 & $(1.1)$ & 228 \\
\hline Pyraclostrobin & $\mathrm{F}$ & 40 & 33 & 3.1 & 4.8 & 42 & 15.2 & 239 \\
\hline Pyrimethanil & $\mathrm{F}$ & 28 & 8 & na & 6.0 & 32 & $(1.2)$ & $(4.0)$ \\
\hline Chlorpyrifos & 1 & 21 & 0 & nd & nd & 25 & 3.3 & 65.0 \\
\hline Pendimethalin & $\mathrm{H}$ & 17 & 0 & nd & nd & 20 & 32.7 & 57.4 \\
\hline Trifluralin & $\mathrm{H}$ & 13 & 0 & nd & nd & 13 & $(0.8)$ & 2.1 \\
\hline Ethalfluralin & $\mathrm{H}$ & 10 & 0 & nd & nd & 12 & 4.0 & 34.4 \\
\hline Methylparathion & I & 10 & 0 & nd & nd & 12 & 41.6 & 65.4 \\
\hline$p p^{\prime}-\mathrm{DDE}$ & D & 8 & 0 & nd & nd & 10 & $(1.4)$ & (3.2) \\
\hline bifenthrin & 1 & 8 & 0 & nd & nd & 19 & 4.8 & 7.0 \\
\hline $\begin{array}{l}\text { S-ethyl dipropylthiocarbamate } \\
\text { (EPTC) }\end{array}$ & $\mathrm{H}$ & 6 & 0 & nd & nd & 7 & 45.0 & 56.3 \\
\hline Cyprodinil & $\mathrm{F}$ & 6 & 0 & nd & nd & 7 & $(4.0)$ & 180 \\
\hline Zoxamide & $\mathrm{F}$ & 4 & 0 & nd & nd & 5 & 23.8 & 493 \\
\hline Dacthal & $\mathrm{H}$ & 3 & 0 & nd & nd & 3 & 6.1 & 6.5 \\
\hline Fludioxinil & $\mathrm{F}$ & 3 & 0 & nd & nd & 3 & (3.3) & (3.3) \\
\hline Carbofuran & 1 & 1 & 0 & nd & nd & 2 & na & 94.0 \\
\hline Simazine & $\mathrm{H}$ & 1 & 8 & na & 140 & 0 & nd & nd \\
\hline Diazinon & 1 & 1 & 0 & nd & nd & 2 & na & 1.7 \\
\hline Fipronil & 1 & 1 & 8 & na & $(2.2)$ & 0 & nd & nd \\
\hline Fenhexamide & $\mathrm{F}$ & 1 & 8 & na & 116 & 0 & nd & nd \\
\hline Malathion & 1 & 1 & 0 & nd & nd & 2 & na & 249 \\
\hline Triticonazole & $\mathrm{F}$ & 1 & 0 & nd & nd & 2 & na & 66.8 \\
\hline Dimethomorph & $\mathrm{F}$ & 1 & 8 & na & 33.3 & 0 & nd & nd \\
\hline
\end{tabular}

na: median not calculated when the compound was only detected once during sampling

nd: not detected.

Table 3: Summary of the pesticides detected, pesticide type, detection frequency, and median and maximum observed concentrations in surface water and groundwater samples. Resultsin parentheses are less than the method detection limit and are estimated. (F: fungicide; H: herbicide; I: insecticide; D: degradate). (Adopted from Reilly et al. [149]).

6-chloronicotinic acid (6CNA). The presence of 6CNA was confirmed in soil [161]. Due to its widespread use, persistence, and aquatic toxicity, the potential for transport from agricultural fields to surface water is a concern [162]. Starner et al. [163] has conducted a screening of imidacloprid in three agricultural regions of California and the results showed that Imidacloprid was detected in 67 samples out of 75 surface water samples collected (89\%). The concentrations exceeded the United States Environmental Protection Agency's chronic invertebrate Aquatic Life Benchmark of $1.05 \mu \mathrm{g} / \mathrm{L}$ in 14 samples (19\%). The data of occurrence of imidacloprid in surface water in other parts of the United States is still very limited or not available.

For assessment of neonicotinoids, a HPLC-MS/MS method has been developed for simultaneous determination of imidacloprid and the olefinic imidacloprid, guanidine, olefinic guanidine, urea metabolites in water samples $[164,165]$. The method detection limit (MDL) for imidacloprid was $0.010 \mu \mathrm{g} / \mathrm{L}$; the reporting limit (RL) was $0.050 \mathrm{~g} / \mathrm{L}$. The blank-matrix spike recovery performances were $83 \%-114 \%$. Several GC-MS methods were reported to determine imidacloprid and other neonicotinoids. Nguyen et al. [166] developed a GC-MS method for determination of imidacloprid and acetamiprid in soil samples. The MDLs were 0.005 and $0.007 \mu \mathrm{g} / \mathrm{mL}$ for imidacloprid and acetamiprid and the limit of quantification (LOQ) was $0.02 \mu \mathrm{g} / \mathrm{mL}$. The method had a linear range of $0.05-5.0 \mu \mathrm{g} / \mathrm{mL}$ range and recoveries were 90.4 $93.7 \%$ at $0.5-2 \mathrm{mg} / \mathrm{kg}$ spiking levels. A method for determination of imidacloprid in water and soil samples by GC-MS with selected ion monitoring was also reported by Vilchez et al. [167]. The method has an applicable concentration range of 5-20 $\mu \mathrm{g} / \mathrm{L}$. The MDL was 0.16 $\mu \mathrm{g} / \mathrm{L}$ for water and $1 \mu \mathrm{g} / \mathrm{kg}$ for soil samples.

Some studies have been conducted to investigate the imidacloprid removal from environmental samples. Phytoremediation method was reported to remove imidacloprid from soil and water [168]. In this study, broadleaf plantain plant (Plantago major L.) was used in phytoremediation of imidacloprid. Viable whole broadleaf plantain plant in water solution reduced imidacloprid residues by $55.81-95.17 \%$, during 1-10 days of exposure periods compared with 13.71-61.95\% in water solution without the plantain. The results showed that the growing cells of short-rod gram-negative bacteria that isolated from the water solution containing broadleaf plantain plants was able to induce 93.34\% loss of imidacloprid as a source of both carbon and nitrogen within a short period ( $48 \mathrm{hr}$ ) compared with $31.90 \%$ in un inoculated medium. The half-life in soil planted with broadleaf plantain plants was much shorter than that of unplanted soil (4.8 days vs. 8.4 days). A separate study has demonstrated the degradation of imidacloprid in water by photo-Fenton and $\mathrm{TiO}_{2}$ photocatalysis [169]. The data showed that the degradation of $50 \mathrm{mg} / \mathrm{L}$ of imidacloprid can be achieved within 25 minutes by photo-Fenton and within 100 minutes by $\mathrm{TiO}_{2}$ photocatalysis.

The other removal methodologies for pesticides/herbicides and their degradation products include majorly activated carbon 
adsorption [131,170], reverse osmosis membrane filtration [171], ozone/hydrogen peroxide and ozone/ $\mathrm{TiO}_{2}[172]$, and other low-cost adsorbents. Each of these methods has advantages and disadvantages. While removing parent pesticides effectively, the technologies may not necessarily be effective for the removal of the toxicity, since many of the oxidation products (e.g. Oxon forms of organophosphorus insecticides) are equally or more toxic than the parent compounds. Many different degradants have not been tested for their toxicities and removal methods. More research is in need in this area.

\section{Future Trends in Assessment and Removal of Emerging Water Contaminants}

(1) Even though a tremendous amount of work has been accomplished in the development of analytical technologies and methods for assessment of variety of emerging contaminants in natural and drinking waters, a lot of work still needs to be done to conduct high throughput assessment of emerging contaminants efficiently and accurately at low levels. Removal of emerging contaminants in natural and drinking waters is even more challenging and have a long way to go before they can be quantitatively removed in feasible and economic ways. The following areas are recommended as the major focus for assessing and removing emerging contaminants in natural water bodies and drinking water. Development of new monitoring systems. New instrumental technologies and methods are still required for many emerging contaminants to allow researchers and water treatment facilities to conduct quantitative and high throughput screening of those compounds in trace levels economically. Once some of the emerging contaminants are regulated in drinking water, routine monitoring is required to make sure that the levels of the regulated compounds are under the established limits. However, most of the current technologies, such as UPLC-MS/MS coupled with SPE extraction, are not cost effective and most water treatment facilities, especially in developing countries, may not have the funds nor the expertise required to own such a technology for emerging contaminant screening. The water samples have to be sent to a central laboratory for screening at a huge cost.

(2) Research on new technologies for removal of emerging contaminants in waters will be another top priority in the future years. Once the regulated contaminants show up over the maximum regulated levels, action must be taken to reduce them to harmless levels. The first priority is to remove them from drinking water. However, no effective removal technologies have been discovered or invented to simultaneously remove all of the concerned contaminants up to date, even though some techniques have been demonstrated to remove certain contaminants to certain extent. Nanomaterials have great potential for emerging contaminant removal due to their large specific surface areas. However, they have to be immobilized onto macro-particles such as GAC or PAC to prevent releasing nanomaterials into drinking waters, or else it would create further problems. The removals of DBPs are even more difficult because extra steps must be taken to remove those compounds without adding unnecessary contaminants into the treated water. The best way may be finding efficient ways to remove the precursors of DBPs to prevent formation of DBPs during the disinfection process.

(3) Risk assessment of emerging contaminants. Some studies have shown that some of the emerging contaminants dealt with here are cytotoxic at low levels. However, risk assessments of some compounds are very difficult because of the low concentrations found in waters, and the lack of sufficient monitoring and toxicity data available at the moment. New risk assessment guidelines need to be developed and unified so that all researchers in this area are in the same spectrum, so that assessment data are comparable among different laboratories.

(4) Establish a comprehensive emerging contaminant database. It is well-known that the quality of drinking water and the number of contaminants depend heavily on the quality of the source water (except for disinfection byproducts). The quality of the source water in turn depends on water resources. For example, well water (i.e. ground water) may contain much less organic contaminants than surface water because surface water is more influenced by industrial activities, effluents of municipalities, runoff from agriculture, recreational activities, shipping routes, river bank structures, and so on. Therefore, establishment of a comprehensive emerging contaminant database for each geographic region will help utilize specific treatments to remove the targeted emerging contaminants.

(5) Finally, measurement, risk assessment, and removal of degradates of emerging contaminants will be another issue for researchers to deal with. During the disinfection process, some contaminants may be broken down and degrade to form different chemicals, which -as we have seen- might be even more harmful to humans and animals. Therefore, assessment and removal of the contaminant degradates is even more challenging because their concentrations are even lower than those of the parent compounds. Furthermore, the health risks to humans and animals may be different because of different chemical properties and modes of action. The techniques for removal of the contaminant degradates may also be totally different from their parent compounds because the solubility and polarity may vary significantly from their parental compounds. Much more efforts and time will be required to accomplish this task.

\section{Concluding Remarks}

Although emerging contaminant compounds occur in trace concentrations in waters, their adverse effects to aquatic organisms, animals, and humans cannot be underestimated due to their continuous release into the water systems. The assessment and removal of emerging contaminants and their transformation products in natural and drinking waters are challenging tasks because of the complexity of contaminants in water samples. However, tremendous progress has been made on assessment of many emerging contaminants due to the great efforts and times committed by many scientists working in different research fields. The future trends in assessment and removal of emerging water contaminants will be on the oxidation/degradation products and metabolites of emerging contaminants because they have not yet been fully documented. With the advanced analytical techniques we currently enjoy, these contaminants can be identified and quantified, providing more insight to the occurrence, formation, properties and pathways. Development of feasible techniques to removal these contaminants, including precursors, degradates, and DBPs, is also going to be one of the top priorities in the future years because feasible techniques need to be in place to remove them or at least reduced them below the regulated levels. 
Citation: Shi H, Cheng X, Wu Q, Mu R, Ma Y (2012) Assessment and Removal of Emerging Water Contaminants. J Environ Anal Toxicol S2:003. doi:10.4172/2161-0525.S2-003

\section{References}

1. Thomaidis NS, Asimakopoulos AG, Bletsou AA (2012) Emerging Contaminants: A Tutorial Mini-Review, Global NEST Journal 14: 72-79.

2. Richardson SD, Ternes TA (2011) Water analysis: emerging contaminants and current issues. Anal Chem 83: 4614-4648.

3. Richardson SD (2012) Environmental mass spectrometry: emerging contaminants and current issues. Anal Chem 84: 747-778.

4. Richardson SD (2009) Water analysis: emerging contaminants and current issues. Anal Chem 81: 4645-4677.

5. Richardson SD (2007) Water analysis: emerging contaminants and current issues. Anal Chem 79: 4295-4324.

6. Richardson SD, Ternes TA (2005) Water Analysis: Emerging Contaminants and Current Issues. Anal Chem 77: 3807-3838.

7. Richardson SD (2003) Environmental Mass Spectrometry: Emerging Contaminants and Current Issues, Analytical Chemistry 75: 2831-2857.

8. Richardson SD (2001) Water analysis. Anal Chem 73: 2719-2734.

9. Daughton CG (2004) Non-regulated water contaminants: emerging research Environmental Impact Assessment Review 24: 711-732.

10. Kolpin DW, Furlong ET, Meyer MT, Thurman EM, Zaugg SD, et al. (2002) Pharmaceuticals, hormones, and other organic wastewater contaminants in U.S. streams, 1999-2000: a national reconnaissance. Environ Sci Technol 36 1202-1211.

11. Wang C, Shi H, Adams CD, Gamagedara S, Stayton I, et al. (2011) Investigation of pharmaceuticals in Missouri natural and drinking water using high performance liquid chromatography-tandem mass spectrometry. Water Res 45: 1818-1828.

12. Bueno MJM, Hernando MD, Herrera S, Gomez MJ, Fernandez-Alba AR, et al. (2010) Pilot survey of chemical contaminants from industrial and human activities in river waters of Spain. Int J Environ Anal Chem 90: 321-343.

13. Dougherty JA, Swarzenski PW, Dinicola RS, Reinhard M (2010) Occurrence of herbicides and pharmaceutical and personal care products in surface wate and groundwater around Liberty Bay, Puget Sound, Washington. J Environ Qual 39: 1173-1180.

14. Li H, Helm PA, Metcalfe CD (2010) Sampling in the Great Lakes for pharmaceuticals, personal care products, and endocrine-disrupting substances using the passive polar organic chemical integrative sampler. Environ Toxicol Chem 29: 751-762

15. Peng X, Yu Y, Tang C, Tan J, Huang Q, et al. (2008) Occurrence of steroid estrogens, endocrine-disrupting phenols, and acid pharmaceutical residues in urban riverine water of the Pearl River Delta, South China. Sci Total Environ 397: 158-166.

16. Heberer $T$ (2002) Occurrence, fate, and removal of pharmaceutical residues in the aquatic environment: a review of recent research data. Toxicol Lett 131 5-17.

17. Benotti MJ, Trenholm RA, Vanderford BJ, Holady JC, Stanford BD, et al. (2009) Pharmaceuticals and endocrine disrupting compounds in U.S. drinking water. Environ Sci Technol 43: 597-603.

18. Yu Y, Wu L (2012) Analysis of endocrine disrupting compounds, pharmaceuticals and personal care products in sewage sludge by gas chromatography-mass spectrometry. Talanta 89: 258-263.

19. Farre M, Ferrer I, Ginebreda A, Figueras M, Olivella L, et al. (2001) Determination of drugs in surface water and wastewater samples by liquid chromatographymass spectrometry: methods and preliminary results including toxicity studies with Vibrio fischeri. J Chromatogr A 938: 187-197.

20. Ternes T, Bonerz M, Schmidt T (2001) Determination of neutral pharmaceuticals in wastewater and rivers by liquid chromatography-electrospray tandem mass spectrometry. J Chromatogr A 938: 175-185.

21. Ternes TA (2001) Analytical methods for the determination of pharmaceuticals in aqueous environmental samples. TrAC Trends Anal Chem 20: 419-434.

22. Vanderford BJ, Pearson RA, Rexing DJ, Snyder SA (2003) Analysis of endocrine disruptors, pharmaceuticals, and personal care products in water using liquid chromatography/tandem mass spectrometry. Anal Chem 75: 62656274 .
23. Vanderford BJ, Snyder SA (2006) Analysis of pharmaceuticals in water by isotope dilution liquid chromatography/tandem mass spectrometry. Environ Sci Technol 40: 7312-7320.

24. Wang $C$, Shi $H$, Adams CD, Timmons $T$, Ma $Y$ (2011) Investigation of oxidative and PAC removal of selected pharmaceuticals in various oxidation systems by using liquid chromatography tandem mass spectrometry. Global Journal of Analytical Chemistry 2: 142-151.

25. Ye Z, Weinberg HS, Meyer MT (2007) Trace analysis of trimethoprim and sulfonamide, macrolide, quinolone, and tetracycline antibiotics in chlorinated drinking water using liquid chromatography electrospray tandem mass spectrometry. Anal Chem 79: 1135-1144.

26. Rodil R, Quintana JB, López-Mahía P, Muniategui-Lorenzo S, Prada-Rodríguez $D(2008)$ Multiclass determination of sunscreen chemicals in water samples by liquid chromatography-tandem mass spectrometry. Anal Chem 80: 1307-1315.

27. EPA US (2007) Method 1694: Pharmaceuticals and Personal Care Products in Water, Soil, Sediment, and Biosolids by HPLC/MS/MS. U.S. Environmental Protection Agency, Washington, DC.

28. Baronti C, Curini R, D’Ascenzo G, Di Corcia A, Gentili A, et al. (2000) Monitoring natural and synthetic estrogens at activated sludge sewage treatment plants and in a receiving river water. Environ Sci Technol 34: 5059-5066.

29. Broséus R, Vincent S, Aboulfadl K, Daneshvar A, Sauvé S, et al. (2009) Ozone oxidation of pharmaceuticals, endocrine disruptors and pesticides during drinking water treatment. Water Res 43: 4707-4717.

30. Hua W, Bennett ER, Letcher RJ (2006) Ozone treatment and the depletion of detectable pharmaceuticals and atrazine herbicide in drinking water sourced from the upper Detroit River, Ontario, Canada. Water Res 40: 2259-2266.

31. Huber MM, Canonica S, Park GY, von Gunten U (2003) Oxidation of pharmaceuticals during ozonation and advanced oxidation processes. Environ Sci Technol 37: 1016-1024.

32. Kim JW, Jang HS, Kim JG, Ishibashi H, Hirano M, et al (2009) Occurrence of pharmaceutical and personal care products (PPCPs) in surface water from Mankyung River, South Korea. Journal of Health Science 55: 249-258.

33. Nakada N, Komori K, Suzuki Y, Konishi C, Houwa I, et al. (2007) Occurrence of 70 pharmaceutical and personal care products in Tone River basin in Japan. Water Sci Technol 56: 133-140.

34. Stackelberg PE, Gibs J, Furlong ET, Meyer MT, Zaugg SD, et al. (2007) Efficiency of conventional drinking-water-treatment processes in removal of pharmaceuticals and other organic compounds. Sci Total Environ 377: 255272.

35. Wang C, Gibbons SE, Ma Y (2010) Removal of carbamazepine in water samples using nanoparticles, microbeads and powdered activated carbon. $J$ Undergrad Chem Res 9: 6-10.

36. Westerhoff $P$, Yoon $Y$, Snyder S, Wert E (2005) Fate of endocrine-disruptor pharmaceutical, and personal care product chemicals during simulated drinking water treatment processes. Environ Sci Technol 39: 6649-6663.

37. Zwiener C, Frimmel FH (2000) Oxidative treatment of pharmaceuticals in water Water Res 34: 1881-1885.

38. Chamberlain E, Adams C (2006) Oxidation of sulfonamides, macrolides, and carbadox with free chlorine and monochloramine. Water Res 40: 2517-2526.

39. Carballa M, Manterola G, Larrea L, Ternes T, Omil F, et al. (2007) Influence of ozone pre-treatment on sludge anaerobic digestion: removal of pharmaceutical and personal care products. Chemosphere 67: 1444-1452.

40. Kim SD, Cho J, Kim IS, Vanderford BJ, Snyder SA (2007) Occurrence and removal of pharmaceuticals and endocrine disruptors in South Korean surface, drinking, and waste waters. Water Res 41: 1013-1021.

41. Ramsey T, Wang C, Ma Y (2012) Removal efficiency of sulfamethoxazole in water samples using nanomaterials. J Undergrad Chem Res 11: 27-29.

42. Ohanian EV, Mullin CS, Orme J (1989) Health Effects of Disinfectants and Disinfection By-Products: A Regulatory Perspective. Water Chlorination: Chem Environ Impact Health Effects 6: 75-86.

43. Jobb DB, Hunsinger R, Meresz O, Taguchi VY (1992) A study of the occurrence and inhibition of formation of N-nitrosodimethylamine (NDMA) in the Ohsweken water supply. In Fifth National Conference on Drinking Water, Winnipeg Manitoba, Canada. 
Citation: Shi H, Cheng X, Wu Q, Mu R, Ma Y (2012) Assessment and Removal of Emerging Water Contaminants. J Environ Anal Toxicol S2:003. doi:10.4172/2161-0525.S2-003

44. Charrois JW, Boyd JM, Froese KL, Hrudey SE (2007) Occurrence of $\mathrm{N}$-nitrosamines in Alberta public drinking-water distribution systems. Journal of Environmental Engineering and Science 6: 103-114.

45. Huy NV, Murakami M, Sakai H, Oguma K, Kosaka K, et al. (2011) Occurrence and formation potential of $\mathrm{N}$-nitrosodimethylamine in ground water and river water in Tokyo. Water Res 45: 3369-3377.

46. Wang W, Ren S, Zhang H, Yu J, An W, et al. (2011) Occurrence of nine nitrosamines and secondary amines in source water and drinking water: Potential of secondary amines as nitrosamine precursors. Water Res 45: 49304938.

47. Mhlongo SH, Mamba BB, Krause RW (2009) Nitrosamines: A review on their prevalence as emerging pollutants and potential remediation options. Water SA 35: $735-740$

48. Wang C, Shi H, Adams CD, Timmons T, Ma Y (2012) Investigation of removal of $\mathrm{N}$-nitrosamines and their precursors in water treatments using activated carbon nanoparticles and liquid chromatography-tandem mass spectrometry. International Journal of Environment Technology and Management In press.

49. Cheng $X$, Shi H, Adams CD, Timmons T, Ma Y (2011) Removal Study of $\mathrm{N}$-Nitrosamines by Powdered Activated Carbon in Natural and Reagent Water using SPE-LC-MS/MS. Global Journal of Analytical Chemistry 2: 232-240.

50. Zwiener CZ, Richardson SD (2005) Analysis of disinfection by-products in drinking water by LC-MS and related MS techniques. TrAC Trends in Analytical Chemistry 24: 613-621.

51. Richardson SD (2003) Disinfection by-products and other emerging contaminants in drinking water. TrAC Trends in Analytical Chemistry 22: 666684.

52. Richardson SD (2002) The role of GC-MS and LC-MS in the discovery of drinking water disinfection by-products. J Environ Monit 4: 1-9.

53. Shi H, Adams C (2009) Rapid IC-ICP/MS method for simultaneous analysis of iodoacetic acids, bromoacetic acids, bromate, and other related halogenated compounds in water. Talanta 79: 523-527.

54. Bolto B, Dixon D, Eldridge R, King S (2002) Removal of THM precursors by coagulation or ion exchange. Water Res 36: 5066-5073.

55. Matilainen A, Sillanpaa M (2010) Removal of natural organic matter from drinking water by advanced oxidation processes. Chemosphere 80: 351-365

56. Singh G, Rana D, Matsuura T, Ramakrishna S, Narbaitz RM, et al. (2010) Removal of disinfection byproducts from water by carbonized electrospun nanofibrous membranes. Separation and Purification Technology 74: 202-212.

57. Tan Y, Kilduff JE, Kitis M, Karanfil T (2005) Dissolved organic matter removal and disinfection byproduct formation control using ion exchange. Desalination 176: $189-200$.

58. Codd GA (1995) Cyanobacterial toxins: occurrence, properties and biologica significance. Water Science and Technology 32: 149-156.

59. Shaw GR, Sukenik A, Livne A, Chiswell RK, Smith MJ, et al. (1999) Blooms of the cylindrospermopsin containing cyanobacterium, Aphanizomenon ovalisporum (Forti), in newly constructed lakes, Queensland, Australia. Environmental Toxicology 14: 167-177.

60. Fastner J, Heinze R, Humpage AR, Mischke U, Eaglesham GK, et al (2003) Cylindrospermopsin occurrence in two German lakes and preliminary assessment of toxicity and toxin production of Cylindrospermopsis raciborski (Cyanobacteria) isolates. Toxicon 42: 313-321.

61. Bouaïcha N, Nasri AB (2004) First report of cyanobacterium Cylindrospermopsis raciborskii from Algerian freshwaters. Environ Toxicol 19: 541-543.

62. Nogueira IC, Saker ML, Pflugmacher S, Wiegand C, Vasconcelos VM (2004) Toxicity of the cyanobacterium Cylindrospermopsis raciborskii to Daphnia magna. Environ Toxicol 19: 453-459.

63. Ramsdell JS, Anderson DM, Gilbert PM (2005) Ecological Society of America 96.

64. Glibert PM, Anderson DM, Gentien P, Graneli E, Sellner KG (2005) Oceanography 18

65. Burkholder JM, Azanza RV, Sako Y (2006) Ecology of Harmful Algae.

66. Ho L, Meyn T, Keegan A, Hoefel D, Brookes J, et al. (2006) Bacteria degradation of microcystin toxins within a biologically active sand filter. Water Res 40: 768-774
67. Fastner J, Ruecker J, Stueken A, Preussel K, Nixdorf B, et al. (2007) Occurrence of the cyanobacterial toxin cylindrospermopsin in Northeas Germany. Environmental Toxicology 22: 26-32.

68. Yilmaz M, Phlips EJ, Szabo NJ, Badylak S (2008) A comparative study of Florida strains of Cylindrospermopsis and Aphanizomenon for cylindrospermopsin production. Toxicon 51: 130-139.

69. Haider S, Naithani V, Viswanathan PN, Kakkar P (2003) Cyanobacterial toxins: a growing environmental concern. Chemosphere 52: 1-21.

70. EPA (2012) Cyanobacterial and cyanotoxins: information for drinking water systems

71. Llewellyn LE (2006) Saxitoxin, a toxic marine natural product that targets a multitude of receptors. Nat Prod Rep 23: 200-222.

72. Van Apeldoorn ME, van Egmond HP, Speijers GJ, Bakker GJ (2007) Toxins of cyanobacteria. Mol Nutr Food Res 51: 7-60.

73. Norris RL, Eaglesham GK, Shaw GR, Senogles P, Chiswell RK, et al. (2001) Extraction and purification of the zwitterions cylindrospermopsin and deoxycylindrospermopsin from Cylindrospermopsis raciborskii. Environ Toxico 16: 391-396.

74. Duy TN, Lam PK, Shaw GR, Connell DW (2000) Toxicology and risk assessment of freshwater cyanobacterial (blue-green algal) toxins in water Rev Environ Contam Toxicol 163: 113-185.

75. Carmichael WW, Azevedo SM, An JS, Molica RJ, Jochimsen EM, et al. (2001) Human fatalities from cyanobacteria: chemical and biological evidence fo cyanotoxins. Environ Health Perspect 109: 663-668.

76. Saker ML, Griffiths DJ (2001) Occurrence of blooms of the cyanobacterium cylindrospermopsis raciborskii (Woloszynska) Seenayya and Subba Raju in a North Queensland domestic water supply. Marine and Freshwater Research 52: $907-915$

77. Briand JF, Robillot C, Quiblier-Llobéras C, Humbert JF, Couté A, et al. (2002) Environmental context of Cylindrospermopsis raciborskii (Cyanobacteria) blooms in a shallow pond in France. Water Res 36: 3183-3192.

78. Lawrence JF, Ménard C, Charbonneau CF, Hall S (1991) A study of ten toxins associated with paralytic shellfish poison using prechromatographic oxidation and liquid chromatography with fluorescence detection. J Assoc Off Anal Chem 74: 404-409.

79. Namikonshi MKLR, Sakai R, Stotts RR, Dahlem AM, Beasley VR, et al. (1992) J Org Chem 57: 866-872

80. Suzuki M, Ha K (1991) 39th Proceedings ASMS Conference on Mass Spectrometry and Allied Topics 1382-1383.

81. Kondo F, Ikai Y, Oka H, Ishikawa N, Watanabe MF, et al. (1992) Separation and identification of microcystins in cyanobacteria by frit-fast atom bombardment liquid chromatography/mass spectrometry. Toxicon 30: 227-237.

82. Rodríguez V, Yonamine M, Pinto E (2006) Determination of anatoxin-a in environmental water samples by solid-phase microextraction and gas chromatography-mass spectrometry. J Sep Sci 29: 2085-2090.

83. Cheng $\mathrm{X}$, Shi H, Adams CD, Timmons T, Ma Y (2009) Effects of oxidative and physical treatments on inactivation of Cylindrospermopsis raciborskii and removal of cylindrospermopsin. Water Sci Technol 60: 689-697.

84. Cheng X, Shi H, Adams CD, Timmons T, Ma Y (2010) Simultaneous screening of herbicide degradation byproducts in water treatment plants using high performance liquid chromatography-tandem mass spectrometry. J Agric Food Chem 58: 4588-4593.

85. Poon GK, Griggs LJ, Edwards C, Beattie KA, Codd GA, et al. (1993) J Chromatogr 628: 215-233.

86. Hummert C, Dahlmann J, Reinhardt K, Dang H, Ph H, et al. (2001) 54: 569-575

87. Bogialli S, Bruno M, Curini R, Di Corcia A, Fanali C, et al. (2006) Monitoring algal toxins in lake water by liquid chromatography tandem mass spectrometry. Environ Sci Technol 40: 2917-2923.

88. Hiller S, Krock B, Cembella A, Luckas B (2007) Rapid detection of cyanobacterial toxins in precursor ion mode by liquid chromatography tandem mass spectrometry. J Mass Spectrom 42: 1238-1250.

89. Cheng X, Shi H, Adams CD, Timmons T, Ma Y (2011) LC-MS/MS determination of cyanobacterial toxins in drinking and surface water samples 2: 1-7. 
Citation: Shi H, Cheng X, Wu Q, Mu R, Ma Y (2012) Assessment and Removal of Emerging Water Contaminants. J Environ Anal Toxicol S2:003. doi:10.4172/2161-0525.S2-003

Page 13 of 14

90. Chow CWK, Drikas M, House J, Burch MD, Velzeboer RMA (1999) The impact of conventional water treatment processes on cells of the cyanobacterium Microcystis aeruginosa. Water Research 33: 3253-3262.

91. Chow CWK, Panglisch S, House J, Drikas M, Burch MD, et al. (1997) A study of membrane filtration for the removal of cyanobacterial cells. Journal of Water SRT-Aqua 46: 324-334

92. Gijsbertsen-Abrahamse AJ, Schmidt W, Chorus I, Heijman SGJ (2006) Removal of cyanotoxins by ultrafiltration and nanofiltration. Journal of Membrane Science 276: 252-259.

93. Hart J, Fawell JK, Croll B (1998) The fate of both intra- and extracellular toxins during drinking water treatment. Water Supply 16: 611-616.

94. Newcombe G (2002) Removal of algal toxins from drinking water using ozone and GAC. AWWA Research Foundation Report.

95. Dixon MB, Richard Y, Ho L, Chow CW, O'Neill BK, et al. (2011) Integrated membrane systems incorporating coagulation, activated carbon and ultrafiltration for the removal of toxic cyanobacterial metabolites from Anabaena circinalis. Water Sci Technol 63: 1405-1411.

96. Dixon MB, Falconet C, Ho L, Chow CW, O'Neill BK, et al. (2010) Nanofiltration for the removal of algal metabolites and the effects of fouling. Water Sci Technol 61: 1189-1199.

97. Smith DP, Falls V, Levine AD, MacLeod B, Simpson M, et al. (2002) Nanofiltration to augment conventional treatment for removal of algal toxins taste and odor compounds, and natural organic matter. In Proceedings of the Water Quality Technology Conference.

98. Muntisov MaTP (1996) Removal of algal toxins using membrane technology. Journal of the Australian Water Association 3: 34.

99. Neumann U, Weckesser J (1998) Elimination of microcystin peptide toxins from water by reverse osmosis. Environmental Toxicology and Water Quality 13: 143-148.

100.Ding J, Shi H, Timmons T, Adams C (2010) Release and removal of microcystins from Microcystis during oxidative-, physical-, and UV-based disinfection. J Environmental Engineering 136: 2-11.

101. Honglan S, Ding J, Timmons T, Adams C (2012) pH effects on the adsorption of saxitoxin by powdered activated carbon. Harmful Algae 19: 61-67.

102. Moore M, Kröger R, Jackson C (2010) The role of aquatic ecosystems in the elimination of pollutants. In Ecological Impacts of Toxic Chemicals (SánchezBayo F, van den Brink P, Mann R, Eds.) 288-304.

103. Acero JL, Stemmler K, Von Gunten U (2000) Degradation Kinetics of Atrazine and Its Degradation Products with Ozone and $\mathrm{OH}$ Radicals: A Predictive Tool for Drinking Water Treatment. Environ Sci Technol 34: 591-597.

104. Duirk SE, Collette TW (2006) Degradation of chlorpyrifos in aqueous chlorine solutions: pathways, kinetics, and modeling. Environ Sci Technol 40: 546-551.

105. Evgenidou E, Fytianos K (2002) Photodegradation of triazine herbicides in aqueous solutions and natural waters. J Agric Food Chem 50: 6423-6427.

106. Hladik ML, Roberts AL, Bouwer EJ (2005) Removal of neutral chloroacetamide herbicide degradates during simulated unit processes for drinking water treatment. Water Res 39: 5033-5044.

107.Lopez A, Mascolo G, Tiravanti G, Passino R (1998) Formation of herbicide degradation byproducts during groundwater disinfection: an LC-MS investigation. J Anal Chem 53: 856-860.

108. Mascolo G, Lopez A, James H, Fielding M (2001) By-products formation during degradation of isoproturon in aqueous solution. I: Ozonation. Water Res 35: 1695-1704

109. Miles CJ (1991) Degradation of aldicarb, aldicarb sulfoxide, and aldicarb sulfone in chlorinated water. Environ Sci Technol 25: 1774-1779.

110. Werres F, Fastabend A, Balsaa $P$, Overath $H$ (1996) Studies on the degradation of pesticides in water by the exposure to chlorine. Vom Wasser 87: 39-49.

111. Pascal-Lorber S, Laurent F (2011) Phytoremediation Techniques for Pesticide Contaminations, in Alternative Faming Systems, Biotechnology, Drought Stress and Ecological Fertilisation 6: 77-105.

112. Battaglin W, Fairchild $\mathrm{J}$ (2002) Potential toxicity of pesticides measured in midwestern streams to aquatic organisms. Water Sci Technol 45: 95-102.
113. EPA (2006) Organophosphate Pesticides: Revised Cumulative Risk Assessment (U.S. EPA, W., D.C., Ed.) Pesticides: Health and Safety.

114. Sinclair CJ, Boxall AB (2003) Assessing the ecotoxicity of pesticide transformation products. Environ Sci Technol 37: 4617-4625.

115. Chamberlain E, Shi H, Wang T, Ma Y, Fulmer A, et al. (2012) Comprehensive screening study of pesticide degradation via oxidation and hydrolysis. J Agric Food Chem 60: 354-363.

116. Chamberlain EF, Wang C, Shi H, Adams CD, Ma Y (2010) Oxidative removal and kinetics of fipronil in various oxidation systems for drinking water treatment. J Agric Food Chem 58: 6895-6899.

117. Cheng X, Shi H, Adams CD, Timmons T, Ma Y (2010) Simultaneous screening of herbicide degradation byproducts in water treatment plants using high performance liquid chromatography-tandem mass spectrometry. J Agric Food Chem 58: 4588-4593.

118. Picó Y, Blasco C, Font G (2004) Environmental and food applications of LC tandem mass spectrometry in pesticide-residue analysis: an overview. Mass Spectrom Rev 23: 45-85.

119. Wang C, Chamberlain E, Shi H, Adams C, Ma Y (2011) Investigation of oxidative degradation of molinate in various oxidation treatment systems by using Liquid Chromatography - Tandem Mass Spectrometry. Global Journal of Analytical Chemistry 2: 107-113.

120.Wang T, Chamberlain E, Shi H, Adams CD, Ma Y (2010) Analysis of oxidation byproducts of dyfonate in various oxidant systems using high performance liquid chromatography coupled with quadrupole ion trap mass spectrometry. Toxicol Environ Chem 92: 1-12.

121. Wang T, Chamberlain E, Shi H, Adams CD, Ma Y (2010) Identification of hydrolytic metabolites of dyfonate in alkaline aqueous solutions by using high performance liquid chromatography - UV detection and gas chromatographymass spectrometry. Int J Environ Anal Chem 90: 948-961.

122. Wang T, Chamberlain E, Shi H, Adams CD, Ma Y (2011) Comprehensive studies of aldicarb degradation in various oxidant systems using high performance liquid chromatography coupled with UV detection and quadrupole ion trap mass spectrometry. Int J Environ Anal Chem 91: 97-111.

123. Yokley RA, Mayer LC, Huang SB, Vargo JD (2002) Analytical method for the determination of metolachlor, acetochlor, alachlor, dimethenamid, and their corresponding ethanesulfonic and oxanillic acid degradates in water using SPE and LC/ESI-MS/MS. Analytical Chemistry 74: 3754-3759.

124. Chamberlain E, Adams CD, Ma Y, Wang T, Lin W, et al. (2011) Pesticide degradates in water treatment: Oxidative formation and partitioning parameter estimation. Water Research Foundation and the American Water Works Association 1-122.

125.EPA (2006) Report of the Food Quality Protection Act (FQPA) Tolerance Reassessment Progress and Risk Management Decision (TRED) for Acetochlor, (US, EPA, W, DC, Ed).

126. Hildebrandt A, Lacorte S, Barceló D (2007) Assessment of priority pesticides, degradation products, and pesticide adjuvants in groundwaters and top soils from agricultural areas of the Ebro river basin. Anal Bioanal Chem 387: 14591468.

127. Omote M, Harayama K, Sasaki T, Mochizuki N, Yamashita H (2006) Analysis of simultaneous screening for 277 pesticides in malt and beer by liquid chromatography with tandem mass spectrometry. J Am Soc Brew Chem 64 139-150.

128. Tamimi M, Qourzal S, Assabbane A, Chovelon JM, Ferronato C, et al. (2006) Photocatalytic degradation of pesticide methomyl: determination of the reaction pathway and identification of intermediate products. Photochem Photobiol Sci 5: 477-482.

129. Jiang H, Adams C, Graziano N, Roberson A, McGuire M, et al. (2006) Occurrence and removal of chloro-s-triazines in water treatment plants. Environ Sci Technol 40: 3609-3616.

130.Gunasekara AS, Truong T, Goh KS, Spurlock F, Tjeerdema RS (2007) Environmental fate and toxicology of fipronil. J Pestic Sci 32: 189-199.

131. Ragoucy-Sengler C, Tracqui A, Chavonnet A, Daijardin JB, Simonetti M, et al (2000) Aldicarb poisoning. Hum Exp Toxicol 19: 657-662.

132. Baltran FJ, Alvarez PM, Legube B, Allemane H (1995) Chemical degradation of aldicarb in water using ozone. Journal of Chemical Technology and Biotechnology 62: 272-278. 
Citation: Shi H, Cheng X, Wu Q, Mu R, Ma Y (2012) Assessment and Removal of Emerging Water Contaminants. J Environ Anal Toxicol S2:003. doi:10.4172/2161-0525.S2-003

133. Perkins EJ Jr, Schlenk D (2000) In vivo acetylcholinesterase inhibition, metabolism, and toxicokinetics of aldicarb in channel catfish: role of biotransformation in acute toxicity. Toxicol Sci 53: 308-315

134. Tomlin CDS (2009) The E-Pesticide Manual, v. 6 ed., British Crop Protection Council, Hampshire GU34 2QD, UK.

135. Tsuda T, Kojima M, Harada H, Nakajima A, Aoki S (1998) Pesticides and their oxidation products in water and fish from rivers flowing into Lake Biwa. Bull Environ Contam Toxicol 60: 151-158.

136. Charizopoulos E, Papadopoulou-Mourkidou E (1999) Occurrence of Pesticides in Rain of the Axios River Basin, Greece. Environ Sci Technol 33: 2363-2368.

137. Coupe RH, Welch HL, Pell AB, Thurman EM (2005) Herbicide and degradate flux in the Yazoo River Basin. International Journal of Environmental Analytical Chemistry 85: 1127-1140.

138. Park BJ, Kyung KS, Choi JH, Im GJ, Kim IS, et al. (2005) Environmental fate of the herbicide molinate in a rice-paddy-soil lysimeter. Bull Environ Contam Toxicol 75: 937-944.

139. Sudo M, Kunimatsu T, Okubo T (2002) Concentration and loading of pesticide residues in Lake Biwa basin (Japan). Water Res 36: 315-329.

140.Stone DL, Sudakin DL, Jenkins JJ (2009) Longitudinal trends in organophosphate incidents reported to the National Pesticide Information Center, 1995-2007. Environ Health 8: 18.

141. Kahle M, Buerge IJ, Hauser A, Müller MD, Poiger T (2008) Azole fungicides: occurrence and fate in wastewater and surface waters. Environ Sci Technol 42: 7193-7200.

142. EPA (2012) Pesticide Product Information System (PPIS).

143. Oerke EC (2006) Crop losses to pests. The Journal of Agricultural Science 144: $31-43$

144. Bromilow RH, Evans AA, Nicholls PH (1999) Factors affecting degradation rates of five triazole fungicides in two soil types: 2 . Field studies. Pestic Sci 55: 1135-1142.

145. Taxvig C, Vinggaard AM, Hass U, Axelstad M, Metzdorff S, et al. (2008) Endocrine-disrupting properties in vivo of widely used azole fungicides. Int $\mathrm{J}$ Androl 31: 170-177.

146. Oller I, Malato S, Sanchez-Perez JA, Maldonado MI, Gasso R (2007) Detoxification of wastewater containing five common pesticides by solar AOPs-biological coupled system. Catal Today 129: 69-78.

147. Reilly TJ, Smalling KL, Orlando JL, Kuivila KM (2012) Occurrence of boscalid and other selected fungicides in surface water and groundwater in three targeted use areas in the United States. Chemosphere 89: 228-234.

148. Cserháti T, Szogyi M (2012) Chromatographic determination of fungicides in biological and environmental matrices. New achievements. Biomed Chromatogr 26: 276-282.

149. Chen ZF, Ying GG, Lai HJ, Chen F, Su HC, et al. (2012) Determination of biocides in different environmental matrices by use of ultra-high-performance liquid chromatography-tandem mass spectrometry. Anal Bioanal Chem 404 : 3175-3188.

150. Goewie CE, Hogendoorn EA (1985) Liquid chromatographic determination of the fungicide iprodione in surface water, using on-line preconcentration. Sci Total Environ 47: 349-360.

151.Wegman RCC, Van de BHH (1982) Determination of fungicides and 2-aminobenzimidazole in surface water by reversed-phase high-performance liquid chromatography [water pollution]. Meded Fac Landbouwwet Rijksuniv Gent 47: 361-365.

152. Takagaki K, Owada C, Nitta Y, Aono M, Takechi T, et al. (2010) Analysis of dithiocarbamate fungicides in environmental water by GC/MS using solidphase Microextraction. Ehime-kenritsu Eisei Kankyo Kenkyusho Nenpo 11: 9-14.

153. Papinutti L, Mouso N, Forchiassin F (2006) Removal and degradation of the fungicide dye malachite green from aqueous solution using the system wheat bran-Fomes sclerodermeus. Enzyme Microb Technol 39: 848-853.

154.Dosnon-Olette R, Couderchet M, Eullaffroy P (2009) Phytoremediation of fungicides by aquatic macrophytes: toxicity and removal rate. Ecotoxicol Environ Saf 72: 2096-2101.
155. Stamatis N, Hela D, Konstantinou I (2010) Occurrence and removal of fungicides in municipal sewage treatment plant. J Hazard Mater 175: 829-835.

156. Matsuda K, Buckingham SD, Kleier D, Rauh JJ, Grauso M, et al. (2001) Neonicotinoids: insecticides acting on insect nicotinic acetylcholine receptors. Trends Pharmacol Sci 22: 573-580.

157.Berger T, Miller MG, Horner CM (2000) In vitro fertilization after in vivo treatment of rats with three reproductive toxicants. Reprod Toxicol 14: 45-53.

158. Garrido Frenich A, Egea González FJ, Martínez Vidal JL, Parrilla Vázquez P, Mateu Sánchez M (2000) Determination of imidacloprid and its metabolite 6-chloronicotinic acid in greenhouse air by high-performance liquid chromatography with diode-array detection. J Chromatogr A 869: 497-504.

159. Segura Carretero A, Cruces-Blanco C, Pérez Durán S, Fernández Gutiérrez A (2003) Determination of imidacloprid and its metabolite 6-chloronicotinic acid in greenhouse air by application of micellar electrokinetic capillary chromatography with solid-phase extraction. J Chromatogr A 1003: 189-195.

160. Marín A, Martínez Vidal JL, Egea Gonzalez FJ, Garrido Frenich A, Glass CR, et al. (2004) Assessment of potential (inhalation and dermal) and actual exposure to acetamiprid by greenhouse applicators using liquid chromatography-tandem mass spectrometry. J Chromatogr B Analyt Techno Biomed Life Sci 804: 269-275

161. Ruiz de N, Gomez de BZ, Aranzazu GM, Barrio RJ (1997) Determination of imidacloprid and its major metabolite in soils by liquid chromatography with pulsed reductive amperometric detection. Anal Chim Acta 349: 199-206.

162.EPA U (2008) Problem formulation for imidacloprid environmental fate and ecological risk assessment, in, Washington, DC.

163. Starner K, Goh KS (2012) Detections of the neonicotinoid insecticide imidacloprid in surface waters of three agricultural regions of California, USA 2010-2011. Bull Environ Contam Toxicol 88: 316-321.

164. Amelin VG, Bol'shakov DS, Tretiakov AV (2012) Identification and determination of synthetic pyrethroids, chlorpyriphos, and neonicotinoids in water by gas and liquid chromatography. J Anal Chem 67: 354-359.

165. Kobayashi H (2009) Development of residue analysis for pesticides by LC/MS and LC/MS/MS methods. Bunseki Kagaku 58: 985-997.

166. Nguyen MS, Nguyen NT, Le TM, Nguyen TD, Nguyen TTT GC-MS method fo determination of imidacloprid and acetamiprid in samples of cotton-growing soil in Nha Ho, Ninh Thuan province after sample solid-phase extraction by mixture of silica gel and activated charcoal. Tap Chi Phan Tich Hoa, Ly Va Sinh Hoc 16: 51-56.

167. Vilchez JL, El-Khattabi R, Fernandez J, Gonzalez-Casado A, Navalon A (1996) Determination of imidacloprid in water and soil samples by gas chromatography-mass spectrometry. J Chromatogr A 746: 289-294.

168. Romeh AA (2010) Phytoremediation of water and soil contaminated with imidacloprid pesticide by Plantago major, L. Int J Phytoremediation 12: 188199.

169. Malato S, Caceres J, Agüera A, Mezcua M, Hernando D, et al. (2001) Degradation of imidacloprid in water by photo-Fenton and TiO2 photocatalysis at a solar pilot plant: a comparative study. Environ Sci Technol 35: 4359-4366.

170. Ninkovic MB, Petrovic RD, Lauševic MD (2010) Removal of organochlorine pesticides from water using virgin and regenerated granular activated carbon. J Serb Chem Soc 75: 565-573.

171.EPA (2001) The Incorporation of Water Treatment Effects on Pesticide Removal and Transformations in Food Quality Protection Act (FQPA) Drinking Water Assessments. United States Environmental Protection Agency, Washington, DC 1-38.

172. Ormad MP, Miguel N, Lanao M, Mosteo R, Ovelleiro JL (2010) Effect of Application of Ozone and Ozone Combined with Hydrogen Peroxide and Titanium Dioxide in the Removal of Pesticides From Water. Ozone: Science \& Engineering 32: 25-32.

This article was originally published in a special issue, Emerging Water Contaminants and Treatment handled by Editor(s). Dr. Xiaoliang Cheng, Lawrence Berkeley Lab, USA. 